\title{
Infectious hematopoietic necrosis virus: advances in diagnosis and vaccine development
}

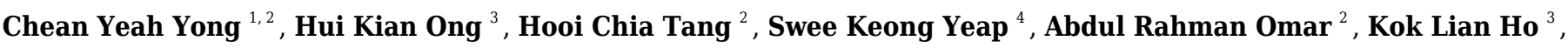 \\ Wen Siang Tan Corresp. 1,2 \\ ${ }^{1}$ Department of Microbiology, Faculty of Biotechnology and Biomolecular Sciences, Universiti Putra Malaysia, Serdang, Selangor, Malaysia \\ 2 Laboratory of Vaccines and Immunotherapeutics, Institute of Bioscience, Universiti Putra Malaysia, Serdang, Selangor, Malaysia \\ 3 Department of Pathology, Faculty of Medicine and Health Sciences, Universiti Putra Malaysia, Serdang, Selangor, Malaysia \\ ${ }^{4}$ China ASEAN College of Marine Sciences, Xiamen University Malaysia, Sepang, Selangor, Malaysia \\ Corresponding Author: Wen Siang Tan \\ Email address: wstan@upm.edu.my
}

The aquaculture of salmonid fishes is a multi-billion dollar industry with production over three million tons annually. However, infectious hematopoietic necrosis virus (IHNV), which infects and kills salmon and trout, reduces significantly the revenue of the salmon farming industry. Currently, there is no effective treatment for IHNV infected fishes, therefore early detection and depopulation of the infected fishes remain the most common practices to contain the spread of IHNV. Apart from hygiene practices in aquaculture and isolation of infected fishes, loss of fishes due to IHNV infection can also be reduced significantly through vaccination programs. In the current review, some of the diagnostic methods for IHNV, spanning from clinical diagnosis to cell culture, serological and molecular methods are discussed in detail. In addition, some of the most significant candidate vaccines for IHNV are also extensively discussed, particularly the DNA vaccines. 
1 Infectious hematopoietic necrosis virus: advances in diagnosis and vaccine development

2

3 Chean Yeah Yong ${ }^{1,2}$, Hui Kian Ong ${ }^{3}$, Hooi Chia Tang ${ }^{2}$, Swee Keong Yeap ${ }^{4}$,

4 Abdul Rahman Omar $^{2}$, Kok Lian $\mathrm{Ho}^{3}$ and Wen Siang Tan ${ }^{1,2}$ *

5

$6{ }^{1}$ Department of Microbiology, Faculty of Biotechnology and Biomolecular Sciences, Universiti

7 Putra Malaysia, Serdang, Selangor, Malaysia.

8 2Laboratory of Vaccines and Immunotherapeutics, Institute of Biosciences, Universiti Putra

9 Malaysia, Serdang, Selangor, Malaysia.

$10{ }^{3}$ Department of Pathology, Faculty of Medicine and Health Sciences, Universiti Putra Malaysia,

11 Serdang, Selangor, Malaysia

$12{ }^{4}$ China ASEAN College of Marine Sciences, Xiamen University Malaysia, Sepang, Selangor, 13 Malaysia.

16 *Correspondence:

17 Wen Siang Tan

18 Department of Microbiology

19 Faculty of Biotechnology and Biomolecular Sciences

20 Universiti Putra Malaysia

2143400 Serdang, Selangor, Malaysia.

22 Tel: 603-89466715; Fax: 603-89430913

23 Email: wstan@upm.edu.my; wensiangtan@yahoo.com 


\section{ABSTRACT}

The aquaculture of salmonid fishes is a multi-billion dollar industry with production over three million tons annually. However, infectious hematopoietic necrosis virus (IHNV), which infects and kills salmon and trout, reduces significantly the revenue of the salmon farming industry. Currently, there is no effective treatment for IHNV infected fishes, therefore early detection and depopulation of the infected fishes remain the most common practices to contain the spread of IHNV. Apart from hygiene practices in aquaculture and isolation of infected fishes, loss of fishes due to IHNV infection can also be reduced significantly through vaccination programs. In the current review, some of the diagnostic methods for IHNV, spanning from clinical diagnosis to cell culture, serological and molecular methods are discussed in detail. In addition, some of the most significant candidate vaccines for IHNV are also extensively discussed, particularly the DNA vaccines.

\section{INTRODUCTION}

Infectious hematopoietic necrosis virus (IHNV) is the causative agent for infectious hematopoietic necrosis in salmonid fishes such as salmon and trout, which represent some of the most important species in aquaculture. Production of worldwide farmed salmon and trout exceeded 3 million tons each year which worth over $\$ 17.5$ billion (Dixon et al. 2016). Due to the high mortality rate of fishes infected by IHNV particularly in younger fishes (up to 90\% or more 
47 in fry), the viral outbreaks have resulted in significant economic losses (Ahmadivand et al. 2017;

48 OIE 2018). The first recorded outbreak occurred in 1950s in blueback salmon brood of 1948

49 (Rucker 1953). Highly susceptible fish species which often lead to high mortality include

50 rainbow trout and steelhead trout (Oncorhynchus mykiss), Chinook salmon (O. tshawytscha),

51 coho salmon (O. kisutch), sockeye salmon (O. nerka), chum salmon (O. keta), Biwa trout $(O$.

52 rhodurus), masu salmon (O. masou), and Atlantic salmon (Salmo salar) (Dixon et al. 2016).

53 IHNV was first isolated from sockeye salmon (Wingfield et al. 1969). It is an enveloped,

54 negative-sense single-stranded RNA virus which belongs to the family of Rhabdoviridae, under

55 the genus Novirhabdovirus with a distinct shape of bullet-like structure. The virion has a size of approximately $150-190 \mathrm{~nm}$ in length and $65-75 \mathrm{~nm}$ in width when observed under an electron

57 microscope (Fig. 1).

Current control methods for IHNV rely on the avoidance of exposure. Therefore,

thorough disinfection of fertilized eggs with disinfectants such as iodophor solution, and the use of virus-free water for rearing such as that obtained from undergrounds or treated with UV or ozone are crucial in preventing IHNV, especially in the early phase of farmed salmonid (OIE 2018). As most of the grow-out phase of the fish occurs in marine environments like net-pens, they could be exposed to viruses shedded from the marine fish reservoirs. Syndromic surveillance is a cost effective approach in minimizing the impact of the virus. If fishes that developed symptoms are separated immediately and culled upon confirmation with a PCR method, farm-wide infections could be prevented (Garver \& Wade 2017). In addition, biosecurity measures such as strict regulations in controlling human and vehicle access to and between farm sites; minimizing contacts between farm fish and wild animals with the use of predators and bird nets; appropriate transport and disposal of fish carcasses, offals and blood 
70 water; low stress husbandry practices; applications of fallow periods between cycles; and 71 sterilizing equipment on regular basis with disinfectants such as Virkon ${ }^{\circledR}$ Aquatic are also 72 important in preventing IHNV outbreaks (Wade 2017). proteins: nucleoprotein $(\mathrm{N})$, polymerase-associated phosphoprotein $(\mathrm{P})$, matrix protein $(\mathrm{M})$, glycoprotein $(\mathrm{G})$, non-structural protein (NV), and RNA-dependent RNA polymerase (L) (Kurath et al. 1985). The $\mathrm{N}$ protein interacts with the viral RNA genome to form the ribonucleoprotein (RNP) complex, which coils into a bullet-shaped structure. The $\mathrm{P}$ and L proteins are associated with the RNP, where they play important roles in the transcription of viral mRNAs and genome replication. The $\mathrm{M}$ protein lines the inner surface of the host-derived envelope, which glues the RNP and envelope together, and packs them into a bullet-like shape. In addition, the $\mathrm{M}$ protein also inhibits the synthesis of host proteins and induces apoptosis

82 (Chiou et al. 2000).

The NV protein is a non-structural protein, which could only be found in infected cells, but not in the virion (Kurath et al. 1985). The NV protein is essential for the pathogenicity of IHNV (Thoulouze et al. 2004). Most recently, Biacchesi et al. (2017) proposed that the NV protein recruits the PPM1Bb protein phosphatase $\left(\mathrm{Mg}^{2+} / \mathrm{Mn}^{2+}\right.$ dependent, $\left.1 \mathrm{Bb}\right)$ to destabilize the innate immune responses of infected fishes (Biacchesi et al. 2017). The G protein, on the other hand, is a class I viral fusion protein which is present in the outermost layer of IHNV. IHNV G proteins form trimeric peplomers, which are responsible for the viral interaction with its host's receptor (Coll 1995). The virus is believed to penetrate the host membrane through receptormediated fibronectin endocytosis (Bearzotti et al. 1999; Liu \& Collodi 2002; Nita-Lazar et al. 92 2016). The $\mathrm{G}$ protein alone is capable of inducing protective immunity against IHNV infection 
93 (Corbeil et al. 1999). Therefore, the $\mathrm{G}$ protein has been studied immensely for vaccine 94 development against IHNV.

95 Current review focuses on the past and recent advances in the diagnosis and vaccine 96 development against IHNV. To the best of our knowledge, there are only 3 review articles

97 focusing on IHNV (Alonso \& Leong 2013; Dixon et al. 2016; Nishizawa \& Yoshimizu 2017) for 98 the past 10 years. Dixon et al. (2016) reviewed on the epidemiology. Nishizawa \& Yoshimizu 99 (2017) reviewed on the epidemiology and virulence changes, as well as the detection and 100 identification of IHNV. Whereas Alonso \& Leong (2013) focused their review on patents on 101 DNA vaccines. Another 2 reviews (Dalmo 2018; Holvold et al. 2014) were on the DNA vaccines 102 for fishes including IHNV. However, none has focused on the diagnosis and vaccine 103 development for IHNV.

104

\section{SURVEY METHODOLOGY}

Recently published journal articles (within 10 years) were searched using the keyword 107 "infectious hematopoietic necrosis virus" in "Scopus" and "Pubmed". The results were screened and relevant articles used as references for this review. In addition, older information was obtained through "Google" search engine with more specific keywords.

\section{DIAGNOSIS OF IHNV}

Early detection of IHNV is crucial in controlling and preventing the spread of this

113 infectious disease since there is no effective treatment for the viral infection. Preliminary 114 diagnosis of IHNV is often based on observation of clinical signs and behavioral changes in the 115 fishes. The outward clinical signs and behavioral changes of the IHNV infected fishes can be 
116 easily recognized and these diagnoses are able to give a presumptive evidence of IHNV infection.

117 However, serological diagnosis methods such as virus neutralization test (VNT) and enzyme-

118 linked immunosorbent assay (ELISA) are still required to confirm the IHNV infection.

119 Molecular diagnostic methods based on PCR and loop-mediated isothermal amplification

120 (LAMP) technologies are generally considered more advanced due to their higher detection

121 sensitivity as compared to the serological methods. These IHNV diagnosis methods will be

122 discussed in detail in the following sections.

124 Clinical diagnosis

Typically, fishes infected by IHNV will become lethargic. The infected fishes will also show abnormal swimming patterns such as sporadic whirling, spiral swimming and flashing.

127 Other symptoms that can be observed through the physical appearance include darkening of the skin color, exophthalmia, pale gills and mucoid, distended abdomens, opaque feces casts, and petechial hemorrhages (Fig. 2) (Woo \& Cipriano 2017).

Several reliable clinical methods for the detection and identification of IHNV are based on the gross and microscopic pathology, chemical pathology, tissue imprints, and electron microscopic analysis. Gross pathological signs of infected fishes include pale internal organs such as liver, kidney, and spleen; distended abdomen with gelatinous substance; exophthalmia; petechial hemorrhages in the muscles and tissues surrounding the organs of the body cavity; and spinal deformities in surviving fishes. Whereas the microscopic pathological signs include necrosis of eosinophilic granular cells in the intestinal wall, and the degenerative necrosis in

137 hematopoietic tissues, digestive tract, kidney, liver, spleen, and pancreas (Schipp 2012). As 138 IHNV can cause renal damage to infected fishes, it can lead to significant changes in the cellular 
139 and chemical blood constituents. By comparing with uninfected fishes, the ill fishes are anemic

140 and leukopenic, with degenerating thrombocytes and leucocytes. A large amounts of cellular

141 debris (necrobiotic bodies) can therefore be observed in the blood (Woo et al. 2011).

142 In IHNV infected fishes, splenic and renal hematopoietic tissues are the first and most

143 severely affected areas. Therefore, the cytopathic effect of the virus can best be observed using

144 tissue imprints prepared from the kidney and spleen. These imprints often show foamy 145 macrophages and necrobiotic debris, indicating IHNV infection (Kibenge \& Godoy 2016).

146 IHNV infection can also be identified through direct observation of virus particles using an

147 electron microscope. The virions can be detected on the cell surface, within cell vacuoles, as well

148 as in the intracellular spaces of the virus-infected cells (OIE 2018).

149 Recently, Burbank et al. (2017) reported a non-lethal sampling technique through fin 150 clipping in adult steelhead trout, followed by the detection of IHNV with cell culture techniques.

151 This method has been demonstrated to be more efficient that the standard lethal sampling 152 methods, such as spleen and anterior kidney sampling (Burbank et al. 2017). The confirmation

153 test or 'gold standard' for IHNV diagnosis is by detecting the virus in cell cultures, followed by 154 diagnosis using immunological and molecular techniques (Barlič-Maganja et al. 2002; Burbank 155 et al. 2017; Crane 2008; Winton 1991; Woo et al. 2011). The presence of IHNV is routinely 156 assessed by observing the development of viral cytopathic effect (CPE) in cell lines such as 157 epithelioma papulosum cyprinid (EPC) and fathead minnow (FHM) under a phase-contrast 158 microscope (Dixon et al. 2016). When virus-like structures are observed in cell cultures with the 159 viral CPE using an electron microscope, a further confirmation test with either the serological 160 method, molecular method, or a combination of both methods is required (OIE 2018). 


\section{Serological diagnosis}

163 Serological diagnosis often requires the use of polyclonal or monoclonal antibodies

164

165

166

167

168

169

170

171

172

173

174

175

176

177

178

179

180

181

182

183

184

which bind specifically to the pathogen. The classic VNT is time consuming as it takes 2 to 8 weeks to complete. Nevertheless, VNT is still being used to detect IHNV infection without sacrificing the fish (Jenčič et al. 2014). More rapid tests based on viral antigen recognition, such as the direct and indirect fluorescent antibody tests (FAT/IFAT) (Arnzen et al. 1991; Lapatra et al. 1989; Woo et al. 2011), ELISA (Adams \& Thompson 2011; Kim et al. 2008), peroxidase immunohistochemical and alkaline phosphatase immunocytochemical (APIC) staining (Drolet et al. 1993; Yamamoto et al. 1990), and western blotting (Ristow et al. 1993) have been successfully developed. FAT/IFAT and APIC staining are often used to detect the presence of IHNV in infected fishes through immunostaining of tissue imprints or fixed tissue sections. Drolet et al. (1993) demonstrated that the APIC assay can detect IHNV in fixed tissue samples over a year old (Drolet et al. 1993).

Similarly, ELISA, dot blotting, and western blotting are used to confirm the presence of IHNV by detecting the viral components with antibodies which bind specifically to the viral antigens. To further contribute to the serological detection of IHNV, Xu et al. (2016) performed a high throughput screening method by using the flow cytometry to select recombinant antibodies which could be used as potential universal diagnostic reagents. Another rapid detection method which is known as the staphylococcal coagglutination test can be used to diagnose IHNV within 15 minutes (Bootland \& Leong 1992; Kim et al. 1994). With the aid of a portable light microscope, this method has the potential to be used as an on-site or point-of-care diagnostic test. However, the staphylococcal coagglutination test is rarely used in the past decade, possibly due to advancements in point-of-care diagnosis using molecular methods. Apart from 
185 using specific antibodies, nucleic acid hybridization probes labeled with biotin or alkaline

186 phosphatase can also be employed to detect the presence of IHNV genomic materials (Gonzalez

187 et al. 1997).

\section{8}

189

Molecular diagnosis

190

The application of molecular diagnosis in clinical microbiology laboratories accelerates

191

the detection and identification of IHNV. Molecular diagnostic methods are generally better than

192

serological methods in terms of sensitivity, as the presence of IHNV genes can be easily

193

amplified with methods such as PCR and LAMP (OIE 2018). Since IHNV is an RNA virus,

reverse transcription- (RT-) PCR is often used to detect the $N$ and $G$ genes of IHNV

(Emmenegger et al. 2000; Knusel et al. 2007). In addition, real-time RT-PCR (qRT-PCR) is also

commonly used to detect IHNV. qRT-PCR generally has a lower risk of contamination, greater

sensitivity, and exclusion of post-PCR analysis as compared to RT-PCR (Dixon et al. 2016; Woo

et al. 2011). More importantly, qRT-PCR is capable of quantifying the viral genome or

transcripts, thereby could be used to determine the health status of an infected fish (Overturf et al. 2001).

Purcell et al. (2013) developed a universal qRT-PCR targeting the $N$ gene of IHNV, and reported a sensitivity and specificity of $100 \%$. As quantitation with qRT-PCR requires the establishment of a standard curve, the results generated from different laboratories could be different. Therefore, RT-droplet digital PCR (RT-ddPCR) has been employed for quantitative detection of IHNV as an alternative to qRT-PCR (Jia et al. 2017). In addition, Pinheiro et al. (2016) developed a multiplex RT-PCR (mRT-PCR) for simultaneous detection of major viruses that infect rainbow trout, including IHNV. In the following year, Tong et al. (2017) also 
208 developed a liquid chip technique for simultaneous detection of IHNV, spring viremia of carp

209 virus (SVCV), and viral hemorrhagic septicemia virus (VHSV) in salmonids, through the use of

210 fluorescence-coded microspheres for hybridization with the RT-PCR products

211 LAMP or RT-LAMP is a powerful diagnostic tool to detect aquaculture diseases as it is 212 rapid and highly sensitive, in which a few copies of cDNA can be amplified by $10^{9}$ folds in less 213 than an hour (Biswas \& Sakai 2014; Fu et al. 2011; Suebsing et al. 2011b). Suebsing et al. 214 (2011a) demonstrated that RT-LAMP can detect as little as $0.01 \mathrm{fg}$ of RNA extracted from 215 IHNV-infected cells. In addition, RT-LAMP is suitable to be applied as a point-of-care IHNV 216 detection tool as the amplification of DNA does not require an expensive thermal cycle, which is 217 a must in PCR-based methods. One of the advantages of LAMP in detecting IHNV is that it 218 allows direct and rapid visualization of the amplified products with naked eyes due to the 219 formation of magnesium pyrophosphate (white precipitate byproduct generated from LAMP), 220 which indicates a successful amplification of the target genomic region (Dhama et al. 2014; 221 Gunimaladevi et al. 2005). This feature makes it applicable in laboratory and field conditions. Ideally, methods established to diagnose IHNV should not be limited to laboratories as they can also be applied in farms which involve a large number of samples. These methods have to be simple, user-friendly, specific, sensitive, rapid, and affordable to fish farmers.

\section{VACCINES AGAINST IHNV}

IHNV has negatively impacted the wild and hatchery-reared salmonid fishes (Rouxel et al. 2016). For the past 30 years, many researchers have tried to develop effective and safe vaccines to control this disease (LaPatra et al. 1994; Romero et al. 2011). As early as 1989, Engelking \& 
231 provided substantial protection to rainbow trout and Kokanee (O. nerka) against IHNV challenge.

232 Five years later, LaPatra et al. (1994) showed that passive immunity against one strain of IHNV

233 cross protected rainbow trout against all other variants. A subsequent study by Roberti et al.

234 (1998) demonstrated that two neutralization-resistant attenuated IHNV mutants, namely RB-1

235 and 193-110-4, conferred significant protection against wild-type IHNV in rainbow trout with a

236 relative percentage of survival (RPS) of $95 \%$ and $100 \%$, respectively. Advancements in

237 biotechnological techniques ignited a spark of interest among researchers to produce the

238 recombinant IHNV G protein in bacteria and yeasts as potential vaccine candidates against the

239 disease (Table 1). In addition, bioinformatics analysis of the IHNV nucleotide sequences

240 deposited in the GenBank suggested that the mutation sites of IHNV G protein under positive

241 selections as potential recombinant vaccine candidates (LaPatra et al. 2008). This idea was

242 adopted by Rouxel et al. (2016) who generated a series of live recombinant IHNV via the reverse

243 genetic approach. This study revealed that the $\mathrm{N}$ protein sequence has the most important role to

244 play in the attenuation of IHNV virulence, and modifications of the $\mathrm{N}$ and $\mathrm{G}$ sequences conferred

245 different degrees of protection and immunity. The details of different types of IHNV vaccines

246 reported in literature are summarized in Table 1.

247 Despite an intensive development of recombinant vaccines against IHNV, biotechnology-

248 based vaccines such as attenuated vaccines, recombinant subunit vaccines, live recombinant

249 vaccines, and even reverse genetic vaccines are not commercially available, where their

250 developments are encumbered by safety concerns toward consumers and environment (Romero

251 et al. 2011). Thus, more efforts are needed in performing major field trials and

252 commercialization of the potential IHNV vaccines listed in Table 1. 


\section{Development of DNA vaccine}

255

256

257

258

259

260

261

262

263

264

265

266

267

268

269

270

271

272

273 274 (Tonheim et al. 2008).

275

276

DNA vaccine is a type of genetic vaccine which involves the introduction of recombinant plasmid encoding an immunogenic antigen into host cells, whereby the antigen could be translated and primes the immune system (van Drunen Littel-van den Hurk et al. 2001). Along with the advancement in genetic engineering, numerous DNA vaccines have been invented in the past three decades and many have entered clinical trials (Ferraro et al. 2011). Although the developed DNA vaccines are more focused on targeting human diseases, DNA vaccines against IHNV were also frequently reported (Alonso et al. 2003; Ferraro et al. 2011; Tonheim et al. 2008). An obvious advantage of DNA vaccines over protein-based vaccines is the scalability and lower cost of production with reduced complexities. DNA vaccines could circumvent most of the problematic issues associated with protein-based vaccines including challenges in protein purification, low protein expression, low protein solubility and protein misfolding (Leitner et al. 1999). Importantly, most DNA vaccines were also demonstrated to be capable of inducing both the cellular and humoral immune responses similar to the live attenuated vaccines (Wang et al. 1998). Moreover, DNA vaccines have a better safety profile in contrary to live attenuated vaccines comprising attenuated pathogens, which may pose a risk of regaining virulence in the host (Pliaka et al. 2012). In addition, plasmid DNA containing immunostimulatory sequence (CpG motifs) also increases the immunogenicity of the vaccine and reduces the reliance on toxic adjuvants which often result in adverse inflammation (Coombes \& Mahony 2001). Plasmid DNA could also be engineered to encode multiple viral antigens to generate multivalent DNA vaccines

Majority of the IHNV DNA vaccines were developed based on the G protein of the IHNV M and $\mathrm{U}$ genotypes, which were found to induce strong humoral immune responses in 
277 immunized fishes (Nichol et al. 1995; Penaranda et al. 2011). DNA vaccines designed based on

278 other internal viral proteins of IHNV such as N, P, M and NV did not induce any significant

279 protective immunogenicity (Corbeil et al. 1999). Recently, an IHNV DNA vaccine encoding the

280 G protein of the J genotype was found to be effective against a wide range of IHNV strains by

281 eliciting strong neutralizing antibody responses and upregulation of $M x-1$ gene, an IFN-inducible

282 antiviral effector (Xu et al. 2017a). On other hand, DNA vaccines which consist of recombinant

283 plasmid encoding the G protein derived from other serologically distant rhabdoviruses: SVCV or

284 snakehead rhabdovirus (SHRV) were also shown to induce notable cross protections in the early

285 (30 days post-vaccination) but not the late (70 days post-vaccination) lethal IHNV challenges

286 (Kim et al. 2000). The G proteins of IHNV, SVCV, and SHRV shared only about $11 \%$ homology

287 in amino acid sequences, therefore protective responses observed during the early IHNV

288 challenge could largely attributed to the non-specific innate immune responses conferred by IFN-

289 inducible antiviral Mx-1 protein. As the nonspecific immune responses faded over time,

290 immunized fishes become more vulnerable to the late IHNV challenge, thus an increased

291 mortality was observed. Nevertheless, fishes immunized with DNA vaccine encoding the G

292 protein of IHNV survived in both the early and late IHNV challenges, suggesting that a long

293 term effective protection requires specific immune responses (Kim et al. 2000). Previous studies

294 have also indicated that co-infection and interactions between infectious pancreatic necrosis

295 virus (IPNV) and IHNV have led to the loss of infective titer of IHNV due to the early release of

296 interfering cytokines which inhibit the viral activities (Alonso et al. 1999; Saint-Jean \& Perez-

297 Prieto 2007; Tafalla et al. 2006). To investigate the capability of IPNV in inducing early cross

298 protection against IHNV, de Las Heras et al. (2009) created a DNA vaccine encoding the VP2

299 protein of IPNV, and demonstrated its protective efficacy against early heterologous IHNV 
300 challenges. Similar results were obtained when DNA vaccine against another rhabdovirus,

301 VHSV was recruited for early IHNV challenge (LaPatra et al. 2001; Lorenzen et al. 2002b).

302 However, the early non-specific cross protection conferred by the rhabdovirus DNA vaccines

303 was shown to be restricted to viral but not bacterial infection as no increment in survival rate was

304 detected when the immunized trout were challenged with bacterial pathogens (Lorenzen et al. 305 2002b).

306

307 Multivalent DNA vaccines

308 VHSV and IHNV are common pathogens endemic to rainbow trout in Europe. Coadministration of IHNV and VHSV DNA vaccines in a single injection in rainbow trout was

310 previously reported to induce long-lasting protections against both individual and combined

311 virus challenges (Boudinot et al. 1998; Einer-Jensen et al. 2009). Dual DNA vaccination could

312 be a viable alternative to avoid repeated stressful vaccination procedures in rainbow trout.

313 However, simultaneous vaccinations of several plasmid DNA encoding different antigens have

314 also been reported to reduce the immunogenicity of the vaccines compared to those administered

315 alone (Sedegah et al. 2004). Remarkably, a recent bivalent DNA vaccine encoding both the G

316 protein of IHNV and VP2-VP3 of IPNV was shown to be highly effective in rainbow trout

317 against individual and simultaneous IHNV and IPNV challenges. In all cases, the RPS was over

$31890 \%$ ( $\mathrm{Xu}$ et al. 2017b). Multivalent vaccines have an added advantage over multi-DNA

319 vaccination due to lower cost of production, as only one type of plasmid is required to produce

320 multiple immunogenic antigens. However, the size of plasmid can affect its transformation into

321 both the prokaryotic and eukaryotic cells (Kreiss et al. 1999; Ohse et al. 1995). Therefore, efforts

322 should be given while designing DNA vaccines to minimize the size of recombinant plasmids, 
323 particularly those of multivalent vaccines. Studies on IHNV DNA vaccines are summarized in 324 Table 2.

\section{Factors affecting the efficacy of DNA vaccines} route of immunization. Intramuscular injection is the most common DNA immunization technique employed in aquaculture, particularly fishes (Corbeil et al. 2000a; Garver et al. 2005b; Lorenzen et al. 2002a; Penaranda et al. 2011; Xu et al. 2017a). Corbeil et al. (2000a) demonstrated that gene gun and intramuscular injection are the most efficient DNA delivery methods as measured by the protective efficacy on the immunized rainbow trout fry challenged with IHNV, whereas intraperitoneal injection induced partial protection. Nevertheless, other routes of DNA immunization including intrabuccal administration, scarification of the skin and the immersion method were shown to be ineffective against IHNV challenge (Corbeil et al. 2000a). Although DNA vaccination via injection method is highly effective against IHNV, this technique is stressful to fishes, time consuming and laborious (Corbeil et al. 2000a). oral vaccination requires the DNA to be protected from degradation in the digestive tract. Adomako et al. (2012) utilized a copolymer, poly (D, L-lactic-co-glycolic acid) (PLGA) as a nanocarrier for the delivery of oral DNA vaccine, where a slight protection towards immunized

342 fishes was reported. Recently, Ballesteros et al. (2015) encapsulated the DNA encoding G 343 protein of IHNV with an alginate microsphere, and orally vaccinated the rainbow trout. Their 344 results revealed that the DNA vaccine was effectively protected in the fish gut by the alginate 345 microsphere, resulting in a significant reduction in mortality of the immunized fishes. To date, 
346 oral vaccination is less effective compared to intramuscular injection. However, further

347 optimization in the future could possibly enhance the protective efficacy of these vaccines.

348 Therefore, it represents a viable alternative in aquaculture, in which it is more practical: lower

349 cost and less laborious.

350 DNA vaccine delivery by attenuated bacteria via horizontal gene transfer was also

351 previously suggested to be a suitable route of immunization in aquaculture due to its low labor

352 cost. Despite successful demonstration of GFP gene transfer into salmonid fish cells via

353 attenuated invasive E. coli, in vitro or in vivo gene transfer of IHNV G protein into fish cells has

354 not been conducted (Simon \& Leong 2002).

355 The efficacy of IHNV DNA vaccines has been reported to be dose dependent (Ballesteros

356 et al. 2015; Corbeil et al. 2000b; Garver et al. 2005b; LaPatra et al. 2000). In general, a larger

357 fish requires a higher vaccination dose for effective protection against IHNV. A 120 g-fish

358 requires about 100 times higher dosage to achieve similar protective immunity compared to

359 fingerlings of 1 to $3 \mathrm{~g}$ (LaPatra et al. 2000). Lapatra et al. (2002) later demonstrated that $0.1 \mu \mathrm{g}$

360 of IHNV DNA vaccine is sufficient to induce significant protection in rainbow trout fry. As a

361 rule of thumb, to induce sufficient protective immune response in rainbow trout, intramuscular

362 vaccination of at least 10 ng DNA per gram body weight is required (Lorenzen et al. 2002a).

363 IHNV DNA vaccines are most commonly tested on rainbow trout, often resulting in high

364 neutralizing antibodies and survival rate in the fish (Corbeil et al. 1999; Corbeil et al. 2000b;

365 Kim et al. 2000; Lapatra et al. 2002; Xu et al. 2017a). Atlantic salmon was also recruited as an

366 animal model to study the efficacy of IHNV DNA vaccine, where they were greatly protected

367 from IHNV immersion and cohabitation challenges (over 90\% RPS). Furthermore, passive

368 serum transfer from the immunized Atlantic salmon to rainbow trout has also increased the 
369 survival rate of the recipients (Traxler et al. 1999). On other hand, Chinook and sockeye salmon

370 immunized with DNA vaccines also exhibited increased survivability, although to a lesser extend

371 compared to Atlantic salmon and rainbow trout (Garver et al. 2005b).

372 Apart from host differences, external parameters such as temperature also play an

373 important role in determining the efficacy of the DNA vaccines. Lorenzen et al. (2002a)

374 suggested that the DNA vaccine encoding G protein of rabies virus failed to elicit early

375 unspecific protection against IHNV could be due to the low water temperature. Intriguingly,

376 Lorenzen et al. (2009) later demonstrated that IHNV and VHSV DNA vaccines induced different

377 defense mechanisms in rainbow trout upon VSHV challenge at different temperatures. At low

378 temperature of 5 and $10^{\circ} \mathrm{C}$, IHNV DNA vaccine could induce a prolonged cross protection

379 against VSHV challenge but no significant protection was observed at $15^{\circ} \mathrm{C}$. In addition, the

380 activity of Mx protein and the level of neutralizing antibody of the immunized fish were also

381 found to vary at different temperatures (Lorenzen et al. 2009). Therefore, the effect of vaccines

382 at different water temperatures should be studied to achieve an optimal protection.

383 Vaccine efficacy can be affected by the route of vaccine delivery as different vaccination

384 approaches influence vaccine localization and priming of the immune cells, and consequently

385 affect the systemic immune responses (Zhang et al. 2015). Due to the complexity of different

386 vaccines, hosts, vaccine dosages, types of adjuvant involved, injection volumes and intervals

387 between injections, thus relative immunogenicity of the vaccines administered by different routes

388 could vary considerably (Zhang et al. 2015). The underlying mechanism of different routes of 389 vaccination in affecting DNA vaccine's efficacy in fishes remains elusive. Nevertheless, 390 intramuscular injection is the most widely used method for DNA vaccination in fishes due to its 391 ability to induce potent immune responses (Tonheim et al. 2008). Studies in mice demonstrated 
392 the distribution of plasmid DNA between the muscle body and epimysium following a DNA

393 vaccination, subsequently myocytes and mononuclear cells were shown to rapidly uptake

394 plasmid DNA shortly after intramuscular injection (Hølvold et al. 2014). DNA immunization by 395 gene gun, on the other hand, introduced the DNA plasmid directly into the cytoplasm, 396 presumably resulting in the DNA being processed by antigen presenting cells, and subsequently 397 activating the adaptive immunity (Wang et al. 2008). DNA vaccines delivered via oral route are 398 relatively less laborious but they were shown to be less effective. Oral DNA vaccination required 399 special protection for the plasmid DNA against hostile fish digestive system to prevent DNA 400 degradation before cellular uptake. Even the DNA plasmid was protected from degradation via 401 certain approaches, transfection efficiency of the plasmid DNA in the fish digestive system poses 402 another challenge (Corbeil et al. 2000a). Immersion route is simple and suitable for mass 403 vaccination of fishes. However, transfection efficiency of the plasmid DNA delivered via 404 immersion route is heavily affected by many factors such as the length of immersion time, size 405 of the fish, stress, $\mathrm{pH}$, osmolarity of the vaccine buffer, the water temperature, and the physical 406 properties (particulate or soluble) of the antigen. Each parameter has to be optimized to improve 407 transfection efficiency and immunogenicity of the DNA vaccine (Nakanishi \& Ototake 1997).

\section{Controversial in DNA vaccination}

Despite the tremendous amount of promising results yielded by DNA vaccines against 412 fish pathogens, the introduction of foreign DNA into human foods has always been controversial 413 throughout the past decades (Alonso \& Leong 2013). There is a possibility that the plasmid DNA 414 could integrate into the host genome, leading to insertion mutations. Nevertheless, plasmid DNA 
415 delivered via intramuscular injection into muscle cells exists as an extra-chromosomal DNA, and

416 its integration into the host genome was reported to be negligible (Kanellos et al. 1999; Ledwith

417 et al. 2000; Nichols et al. 1995). To further mitigate this issue, Alonso et al. (2003) developed a

418 DNA vaccine based on the $G$ gene of IHNV, controlled by the interferon regulatory factor $1 \mathrm{~A}$

419 (IRF1A) promoter originated from rainbow trout to prevent its expression in human. In addition,

420 a study by Salonius et al. (2007) also indicated that the potential risk of spontaneous mutations in

421 Atlantic salmon was about 43-folds higher than that caused by DNA vaccination. Furthermore,

422 several studies have suggested that IHNV DNA vaccination of rainbow trout only caused

423 transient histopathological changes in multiple tissues and no long-term histopathological

424 damage was observed (Garver et al. 2005a; Kurath et al. 2006). However, certain regulations

425 such as the Norwegian Gene Technology Act which categorized DNA vaccinated animals as

426 genetically modified organisms (GMO) presents a stringent policy, eventually leading to low

427 public acceptance (Alonso et al. 2011). To eliminate this concern, a self-destructive IHNV DNA

428 vaccine was designed (Alonso et al. 2011). The plasmid DNA contains an inducible fish cell

429 promoter which regulates the expression of $\mathrm{G}$ glycoprotein for protective immune responses, and

$430 \mathrm{a} \mathrm{ZnCl}_{2}$ inducible promoter which controls the expression of IHNV M protein inducing apoptosis

431 of the transfected cells. Upon successful vaccination, fishes were significantly protected from

432 lethal IHNV challenge, and exposure to $\mathrm{ZnCl}_{2}$ induced apoptosis in fish cells containing the

433 DNA vaccine without causing serious toxicity to the fishes (Alonso et al. 2011). This approach

434 could pave way to the development of safer DNA vaccines with higher public acceptance.

435 Although many research groups have patented their inventions, including Kurath et al.

436 (1985) (Patent No.: 5354555), Salonius et al. (2007) (Patent No.: EP1553979A1, CA2498896C,

437 CN100339131C, JP4578973B2, ES2288627T3, DK1553979T3, DE60315858T2, PT1553979E, 
438 AT370746T, AU2003277863B2, WO2004026338A1, NO20051840L, HK1082666A1,

439 CY1107784T1), Alonso et al. (2003) \& Alonso et al. (2011) (Patent No.: WO/2002/069840), and

$440 \mathrm{Xu}$ et al. (2017a) (Patent No.: CN105816871A, CN105861450A), to date, the Apex-IHN ${ }^{\circledR}$

441 manufactured by Aqua Health Ltd (an affiliate of Novartis) is the only licensed IHNV DNA

442 vaccine in Canada and the United States of America (Grunwald \& Ulbert 2015; USDA 2014).

443

444 CONCLUSIONS

445 Up until now, no effective treatment is available for fishes infected by IHNV. Apart from good 446 biosecurity measures, immediate isolation of symptomatic fishes, rapid and accurate diagnosis of 447 IHNV followed by culling of the infected fishes are essential to prevent the virus from spreading 448 to other farm sites, and possibly prevent a farm-wide infection. A combination of both the rapid 449 on-site test (staphylococcal coagglutination test or RT-LAMP) for mass sample screening, and 450 laboratory confirmatory tests (ELISA and RT-PCR) should be performed to achieve a balance 451 between speed and accuracy. Vaccination provides an alternative approach for fish farmers who 452 can afford extra costs to protect their fishes from IHNV infection. As potentially low-cost 453 vaccines such as oral vaccines have yet to show promising results, vaccination may not be 454 applicable to farmers with small capital in the near future. To date, Apex-IHN ${ }^{\circledR}$ is the only 455 licensed DNA vaccine approved in Canada and the United States of America. Despite its 456 outstanding protective efficacy, the use of DNA vaccine is still very limited at the moment. 457 Hence, studies focusing on the safety of DNA vaccines should be encouraged.

458

459

460

REFERENCES 
461

462

463

464

465

466

467

468

469

470

471

472

473

474

475

476

477

478

479

480

481

482

483

484

485

486

487

488

489

490

491

492

493

494

495

496

497

498

499

500

501

502

503

504

505

506

Adams A, and Thompson KD. 2011. Development of diagnostics for aquaculture: challenges and opportunities. Aquaculture Research 42:93-102. doi:10.1111/j.1365-2109.2010.02663.x

Adomako M, St-Hilaire S, Zheng Y, Eley J, Marcum RD, Sealey W, Donahower BC, Lapatra S, and Sheridan PP. 2012. Oral DNA vaccination of rainbow trout, Oncorhynchus mykiss (Walbaum), against infectious haematopoietic necrosis virus using PLGA [Poly(D,LLactic-Co-Glycolic Acid)] nanoparticles. J Fish Dis 35:203-214. 10.1111/j.13652761.2011.01338.x

Ahmadivand S, Soltani M, Mardani K, Shokrpoor S, Hassanzadeh R, Ahmadpoor M, RahmatiHolasoo H, and Meshkini S. 2017. Infectious hematopoietic necrosis virus (IHNV) outbreak in farmed rainbow trout in Iran: Viral isolation, pathological findings, molecular confirmation, and genetic analysis. Virus Res 229:17-23.

https://doi.org/10.1016/j.virusres.2016.12.013

Alonso M, Chiou PP, and Leong JA. 2011. Development of a suicidal DNA vaccine for infectious hematopoietic necrosis virus (IHNV). Fish Shellfish Immunol 30:815-823. 10.1016/j.fsi.2011.01.001

Alonso M, Johnson M, Simon B, and Leong JA. 2003. A fish specific expression vector containing the interferon regulatory factor 1A (IRF1A) promoter for genetic immunization of fish. Vaccine 21:1591-1600.

Alonso M, and Leong JA. 2013. Licensed DNA Vaccines against Infectious Hematopoietic Necrosis Virus (IHNV). Recent Pat DNA Gene Seq 7:62-65.

Alonso M, Rodriguez S, and Perez-Prieto SI. 1999. Viral coinfection in salmonids: infectious pancreatic necrosis virus interferes with infectious hematopoietic necrosis virus. Arch Virol 144:657-673.

Arnzen JM, Ristow SS, Hesson CP, and Lientz J. 1991. Rapid Fluorescent Antibody Tests for Infectious Hematopoeitic Necrosis Virus (IHNV) Utilizing Monoclonal Antibodies to the Nucleoprotein and Glycoprotein. Journal of Aquatic Animal Health 3:109-113. doi:10.1577/1548-8667(1991)003<0109:RFATFI >2.3.CO;2

Ballesteros NA, Alonso M, Saint-Jean SR, and Perez-Prieto SI. 2015. An oral DNA vaccine against infectious haematopoietic necrosis virus (IHNV) encapsulated in alginate microspheres induces dose-dependent immune responses and significant protection in rainbow trout (Oncorrhynchus mykiss). Fish Shellfish Immunol 45:877-888. 10.1016/j.fsi.2015.05.045

Barlič-Maganja D, Štrancar M, Hostnik P, Jenčič V, and Grom J. 2002. Comparison of the efficiency and sensitivity of virus isolation and molecular methods for routine diagnosis of infectious haematopoietic necrosis virus and infectious pancreatic necrosis virus. $J$ Fish Dis 25:73-80. doi:10.1046/j.1365-2761.2002.00337.x

Bearzotti M, Delmas B, Lamoureux A, Loustau AM, Chilmonczyk S, and Bremont M. 1999. Fish rhabdovirus cell entry is mediated by fibronectin. $J$ Virol 73:7703-7709.

Biacchesi S, Merour E, Chevret D, Lamoureux A, Bernard J, and Bremont M. 2017. NV Proteins of Fish Novirhabdovirus Recruit Cellular PPM1Bb Protein Phosphatase and Antagonize RIG-I-Mediated IFN Induction. Sci Rep 7:44025. 10.1038/srep44025

Biswas G, and Sakai M. 2014. Loop-mediated isothermal amplification (LAMP) assays for detection and identification of aquaculture pathogens: current state and perspectives. Appl Microbiol Biotechnol 98:2881-2895. 10.1007/s00253-014-5531-z

Bootland LM, and Leong JA. 1992. Staphylococcal coagglutination, a rapid method of identifying infectious hematopoietic necrosis virus. Appl Environ Microbiol 58:6-13.

Peer] reviewing PDF | (2019:01:34359:1:1:NEW 22 Apr 2019) 
507

508

509

510

511

512

513

514

515

516

517

518

519

520

521

522

523

524

525

526

527

528

529

530

531

532

533

534

535

536

537

538

539

540

541

542

543

544

545

546

547

548

549

550

551

552

Boudinot P, Blanco M, de Kinkelin P, and Benmansour A. 1998. Combined DNA immunization with the glycoprotein gene of viral hemorrhagic septicemia virus and infectious hematopoietic necrosis virus induces double-specific protective immunity and nonspecific response in rainbow trout. Virology 249:297-306. 10.1006/viro.1998.9322

Burbank DR, Fehringer TR, and Chiaramonte LV. 2017. Comparison of Selected Nonlethal Samples from Adult Steelhead for Detection of Infectious Hematopoietic Necrosis Virus Using Cell Culture. J Aquat Anim Health 29:67-73. 10.1080/08997659.2016.1274690

Chiou PP, Kim CH, Ormonde P, and Leong JA. 2000. Infectious hematopoietic necrosis virus matrix protein inhibits host-directed gene expression and induces morphological changes of apoptosis in cell cultures. $J$ Virol 74:7619-7627.

Coll JM. 1995. The glycoprotein G of rhabdoviruses. Arch Virol 140:827-851.

Coombes BK, and Mahony JB. 2001. Dendritic cell discoveries provide new insight into the cellular immunobiology of DNA vaccines. Immunol Lett 78:103-111.

Corbeil S, Kurath G, and LaPatra SE. 2000a. Fish DNA vaccine against infectious hematopoietic necrosis virus: efficacy of various routes of immunisation. Fish Shellfish Immunol 10:711-723. 10.1006/fsim.2000.0286

Corbeil S, Lapatra SE, Anderson ED, Jones J, Vincent B, Hsu YL, and Kurath G. 1999. Evaluation of the protective immunogenicity of the N, P, M, NV and G proteins of infectious hematopoietic necrosis virus in rainbow trout oncorhynchus mykiss using DNA vaccines. Dis Aquat Organ 39:29-36. 10.3354/dao039029

Corbeil S, LaPatra SE, Anderson ED, and Kurath G. 2000b. Nanogram quantities of a DNA vaccine protect rainbow trout fry against heterologous strains of infectious hematopoietic necrosis virus. Vaccine 18:2817-2824.

Crane MSJW, L. M. 2008. Viruses of salmonids: virus isolation in fish cell lines. p 36.

Dalmo RA. 2018. DNA vaccines for fish: Review and perspectives on correlates of protection. $J$ Fish Dis 41:1-9. 10.1111/jfd.12727

de Las Heras AI, Perez Prieto SI, and Rodriguez Saint-Jean S. 2009. In vitro and in vivo immune responses induced by a DNA vaccine encoding the VP2 gene of the infectious pancreatic necrosis virus. Fish Shellfish Immunol 27:120-129. 10.1016/j.fsi.2008.11.021

Dhama K, Karthik K, Chakraborty S, Tiwari R, Kapoor S, Kumar A, and Thomas P. 2014. Loopmediated isothermal amplification of DNA (LAMP): a new diagnostic tool lights the world of diagnosis of animal and human pathogens: a review. Pak J Biol Sci 17:151-166.

Dixon P, Paley R, Alegria-Moran R, and Oidtmann B. 2016. Epidemiological characteristics of infectious hematopoietic necrosis virus (IHNV): a review. Vet Res 47:63. 10.1186/s13567-016-0341-1

Drolet BS, Rohovec JS, and Leong JC. 1993. Serological Identification of Infectious Hematopoietic Necrosis Virus in Fixed Tissue Culture Cells by Alkaline Phosphatase Immunocytochemistry. Journal of Aquatic Animal Health 5:265-269. 10.1577/15488667(1993)005<0265:SIOIHN>2.3.CO;2

Einer-Jensen K, Delgado L, Lorenzen E, Bovo G, Evensen O, Lapatra S, and Lorenzen N. 2009. Dual DNA vaccination of rainbow trout (Oncorhynchus mykiss) against two different rhabdoviruses, VHSV and IHNV, induces specific divalent protection. Vaccine 27:12481253. 10.1016/j.vaccine.2008.12.007

Emmenegger EJ, Meyers TR, Burton TO, and Kurath G. 2000. Genetic diversity and epidemiology of infectious hematopoietic necrosis virus in Alaska. Dis Aquat Organ 40:163-176. 10.3354/dao040163 
553

554

555

556

557

558

559

560

561

562

563

564

565

566

567

568

569

570

571

572

573

574

575

576

577

578

579

580

581

582

583

584

585

586

587

588

589

590

591

592

593

594

595

596

597

598
Engelking HM, and Leong JC. 1989. Glycoprotein from Infectious Hematopoietic Necrosis Virus (IHNV) Induces Protective Immunity against Five IHNV Types. Journal of Aquatic Animal Health 1:291-300. 10.1577/15488667(1989)001<0291:GFIHNV>2.3.CO;2

Ferraro B, Morrow MP, Hutnick NA, Shin TH, Lucke CE, and Weiner DB. 2011. Clinical applications of DNA vaccines: current progress. Clin Infect Dis 53:296-302. 10.1093/cid/cir334

Fu S, Qu G, Guo S, Ma L, Zhang N, Zhang S, Gao S, and Shen Z. 2011. Applications of loopmediated isothermal DNA amplification. Appl Biochem Biotechnol 163:845-850. 10.1007/s12010-010-9088-8

Garver K, and Wade J. 2017. Characterization of infectious hematopoietic necrosis virus (IHNV). DFO Can. Sci. Advis. Sec. Res. Doc. p 2017/2073. vi + 2032 p.

Garver KA, Conway CM, Elliott DG, and Kurath G. 2005a. Analysis of DNA-vaccinated fish reveals viral antigen in muscle, kidney and thymus, and transient histopathologic changes. Mar Biotechnol (NY) 7:540-553. 10.1007/s10126-004-5129-z

Garver KA, LaPatra SE, and Kurath G. 2005b. Efficacy of an infectious hematopoietic necrosis (IHN) virus DNA vaccine in Chinook Oncorhynchus tshawytscha and sockeye O. nerka salmon. Dis Aquat Organ 64:13-22. 10.3354/dao064013

Gonzalez MP, Sanchez X, Ganga MA, Lopez-Lastra M, Jashes M, and Sandino AM. 1997. Detection of the infectious hematopoietic necrosis virus directly from infected fish tissues by dot blot hybridization with a non-radioactive probe. J Virol Methods 65:273-279.

Grunwald T, and Ulbert S. 2015. Improvement of DNA vaccination by adjuvants and sophisticated delivery devices: vaccine-platforms for the battle against infectious diseases. Clinical and experimental vaccine research 4:1-10. 10.7774/cevr.2015.4.1.1

Gunimaladevi I, Kono T, Lapatra SE, and Sakai M. 2005. A loop mediated isothermal amplification (LAMP) method for detection of infectious hematopoietic necrosis virus (IHNV) in rainbow trout (Oncorhynchus mykiss). Arch Virol 150:899-909. 10.1007/s00705-004-0468-7

Holvold LB, Myhr AI, and Dalmo RA. 2014. Strategies and hurdles using DNA vaccines to fish. Vet Res 45:21. 10.1186/1297-9716-45-21

Hølvold LB, Myhr AI, and Dalmo RA. 2014. Strategies and hurdles using DNA vaccines to fish. Veterinary research 45:21-21. 10.1186/1297-9716-45-21

Jenčič V, Hostnik P, Toplak I, and Grilc Fajfar A. 2014. Utility of the viral neutralisation test for detection of antibodies to infectious haematopoietic necrosis virus in rainbow trout (Oncorhynchus mykiss). Bulletin of the European Association of Fish Pathologists 34:175-181.

Jia P, Purcell MK, Pan G, Wang J, Kan S, Liu Y, Zheng X, Shi X, He J, Yu L, Hua Q, Lu T, Lan W, Winton JR, Jin N, and Liu H. 2017. Analytical validation of a reverse transcriptase droplet digital PCR (RT-ddPCR) for quantitative detection of infectious hematopoietic necrosis virus. $J$ Virol Methods 245:73-80. 10.1016/j.jviromet.2017.03.010

Kanellos T, Sylvester ID, Ambali AG, Howard CR, and Russell PH. 1999. The safety and longevity of DNA vaccines for fish. Immunology 96:307-313.

Kibenge FS, and Godoy M. 2016. Aquaculture virology: Academic Press.

Kim CH, Johnson MC, Drennan JD, Simon BE, Thomann E, and Leong JA. 2000. DNA vaccines encoding viral glycoproteins induce nonspecific immunity and Mx protein synthesis in fish. J Virol 74:7048-7054.

PeerJ reviewing PDF | (2019:01:34359:1:1:NEW 22 Apr 2019) 
599

600

601

602

603

604

605

606

607

608

609

610

611

612

613

614

615

616

617

618

619

620

621

622

623

624

625

626

627

628

629

630

631

632

633

634

635

636

637

638

639

640

641

642

643

644
Kim CH, Winton JR, and Leong JC. 1994. Neutralization-resistant variants of infectious hematopoietic necrosis virus have altered virulence and tissue tropism. Journal of Virology 68:8447-8453.

Kim W-S, Mochizuki M, Nishizawa T, and Yoshimizu M. 2008. Detection of Specific Antibodies against Infectious Hematopoietic Necrosis Virus from Rainbow Trout Sera by ELISA using Two Novirhabdoviruses. Fish Pathology 43:112-116. 10.3147/jsfp.43.112

Knusel R, Bergmann SM, Einer-Jensen K, Casey J, Segner H, and Wahli T. 2007. Virus isolation vs RT-PCR: which method is more successful in detecting VHSV and IHNV in fish tissue sampled under field conditions? J Fish Dis 30:559-568. 10.1111/j.13652761.2007.00842.x

Kreiss P, Cameron B, Rangara R, Mailhe P, Aguerre-Charriol O, Airiau M, Scherman D, Crouzet J, and Pitard B. 1999. Plasmid DNA size does not affect the physicochemical properties of lipoplexes but modulates gene transfer efficiency. Nucleic acids research 27:3792-3798.

Kurath G, Ahern KG, Pearson GD, and Leong JC. 1985. Molecular cloning of the six mRNA species of infectious hematopoietic necrosis virus, a fish rhabdovirus, and gene order determination by R-loop mapping. J Virol 53:469-476.

Kurath G, Garver KA, Corbeil S, Elliott DG, Anderson ED, and LaPatra SE. 2006. Protective immunity and lack of histopathological damage two years after DNA vaccination against infectious hematopoietic necrosis virus in trout. Vaccine 24:345-354. 10.1016/j.vaccine.2005.07.068

LaPatra SE, Corbeil S, Jones GR, Shewmaker WD, and Kurath G. 2000. The Dose-Dependent Effect on Protection and Humoral Response to a DNA Vaccine against Infectious Hematopoietic Necrosis (IHN) Virus in Subyearling Rainbow Trout. Journal of Aquatic Animal Health 12:181-188. 10.1577/1548-8667(2000)012<0181:FDDEOP>2.0.CO;2

LaPatra SE, Corbeil S, Jones GR, Shewmaker WD, Lorenzen N, Anderson ED, and Kurath G. 2001. Protection of rainbow trout against infectious hematopoietic necrosis virus four days after specific or semi-specific DNA vaccination. Vaccine 19:4011-4019.

LaPatra SE, Evilia C, and Winston V. 2008. Positively selected sites on the surface glycoprotein (G) of infectious hematopoietic necrosis virus. J Gen Virol 89:703-708. 10.1099/vir.0.83451-0

LaPatra SE, Lauda KA, and Jones GR. 1994. Antigenic variants of infectious hematopoietic necrosis virus and implications for vaccine development. Diseases of Aquatic Organisms 20:119-126. 10.3354/dao020119

Lapatra SE, Lorenzen N, and Kurath G. 2002. A DNA Vaccine Against Infectious Hematopoietic Necrosis Virus. Fisheries science 68:1151-1156. 10.2331/fishsci.68.sup2_1151

Lapatra SE, Roberti KA, Rohovec JS, and Fryer JL. 1989. Fluorescent Antibody Test for the Rapid Diagnosis of Infectious Hematopoietic Necrosis. Journal of Aquatic Animal Health 1:29-36. doi:10.1577/1548-8667(1989)001<0029:FATFTR>2.3.CO;2

Ledwith BJ, Manam S, Troilo PJ, Barnum AB, Pauley CJ, Griffiths TG, 2nd, Harper LB, Schock HB, Zhang H, Faris JE, Way PA, Beare CM, Bagdon WJ, and Nichols WW. 2000. Plasmid DNA vaccines: assay for integration into host genomic DNA. Dev Biol (Basel) 104:33-43.

Leitner WW, Ying H, and Restifo NP. 1999. DNA and RNA-based vaccines: principles, progress and prospects. Vaccine 18:765-777.

Peer) reviewing PDF | (2019:01:34359:1:1:NEW 22 Apr 2019) 
645

646

647

648

649

650

651

652

653

654

655

656

657

658

659

660

661

662

663

664

665

666

667

668

669

670

671

672

673

674

675

676

677

678

679

680

681

682

683

684

685

686

687

688

689

Liu X, and Collodi P. 2002. Novel form of fibronectin from zebrafish mediates infectious hematopoietic necrosis virus infection. J Virol 76:492-498.

Lorenzen E, Einer-Jensen K, Rasmussen JS, Kjaer TE, Collet B, Secombes CJ, and Lorenzen N. 2009. The protective mechanisms induced by a fish rhabdovirus DNA vaccine depend on temperature. Vaccine 27:3870-3880. 10.1016/j.vaccine.2009.04.012

Lorenzen N, Lorenzen E, Einer-Jensen K, and LaPatra SE. 2002a. DNA vaccines as a tool for analysing the protective immune response against rhabdoviruses in rainbow trout. Fish Shellfish Immunol 12:439-453.

Lorenzen N, Lorenzen E, Einer-Jensen K, and LaPatra SE. 2002b. Immunity induced shortly after DNA vaccination of rainbow trout against rhabdoviruses protects against heterologous virus but not against bacterial pathogens. Dev Comp Immunol 26:173-179.

Nakanishi T, and Ototake M. 1997. Antigen uptake and immune responses after immersion vaccination. Dev Biol Stand 90:59-68.

Nichol ST, Rowe JE, and Winton JR. 1995. Molecular epizootiology and evolution of the glycoprotein and non-virion protein genes of infectious hematopoietic necrosis virus, a fish rhabdovirus. Virus Res 38:159-173.

Nichols WW, Ledwith BJ, Manam SV, and Troilo PJ. 1995. Potential DNA vaccine integration into host cell genome. Ann N Y Acad Sci 772:30-39.

Nishizawa T, and Yoshimizu M. 2017. Infectious hematopoietic necrosis. Fish Pathology 52:1-5. $10.3147 /$ jsfp. 52.1

Nita-Lazar M, Mancini J, Feng C, Gonzalez-Montalban N, Ravindran C, Jackson S, de Las Heras-Sanchez A, Giomarelli B, Ahmed H, Haslam SM, Wu G, Dell A, Ammayappan A, Vakharia VN, and Vasta GR. 2016. The zebrafish galectins Drgal1-L2 and Drgal3-L1 bind in vitro to the infectious hematopoietic necrosis virus (IHNV) glycoprotein and reduce viral adhesion to fish epithelial cells. Dev Comp Immunol 55:241-252. 10.1016/j.dci.2015.09.007

Ohse M, Takahashi K, Kadowaki Y, and Kusaoke H. 1995. Effects of plasmid DNA sizes and several other factors on transformation of Bacillus subtilis ISW1214 with plasmid DNA by electroporation. Biosci Biotechnol Biochem 59:1433-1437. 10.1271/bbb.59.1433

OIE. 2018. Infectious haematopoietic necrosis. Available at http://www.oie.int/index.php?id=2439\&L=0\&htmfile=chapitre ihn.htm $($ accessed 17 October 2018).

Overturf K, LaPatra S, and Powell M. 2001. Real-time PCR for the detection and quantitative analysis of IHNV in salmonids. J Fish Dis 24:325-333. doi:10.1046/j.13652761.2001.00296.x

Penaranda MM, Lapatra SE, and Kurath G. 2011. Specificity of DNA vaccines against the U and $M$ genogroups of infectious hematopoietic necrosis virus (IHNV) in rainbow trout (Oncorhynchus mykiss). Fish Shellfish Immunol 31:43-51. 10.1016/j.fsi.2011.03.003

Pinheiro ACAS, Volpe E, Principi D, Prosperi S, and Ciulli S. 2016. Development of a multiplex RT-PCR assay for simultaneous detection of the major viruses that affect rainbow trout (Oncorhynchus mykiss). Aquaculture International 24:115-125. 10.1007/s10499-0159912-9

Pliaka V, Kyriakopoulou Z, and Markoulatos P. 2012. Risks associated with the use of liveattenuated vaccine poliovirus strains and the strategies for control and eradication of paralytic poliomyelitis. Expert Rev Vaccines 11:609-628. 10.1586/erv.12.28 
690

691

692

693

694

695

696

697

698

699

700

701

702

703

704

705

706

707

708

709

710

711

712

713

714

715

716

717

718

719

720

721

722

723

724

725

726

727

728

729

730

731

732

733

734

Purcell MK, Thompson RL, Garver KA, Hawley LM, Batts WN, Sprague L, Sampson C, and Winton JR. 2013. Universal reverse-transcriptase real-time PCR for infectious hematopoietic necrosis virus (IHNV). Dis Aquat Organ 106:103-115. 10.3354/dao02644

Ristow SS, Avila Jd, LaPatra SE, and Lauda K. 1993. Detection and characterization of rainbow trout antibody against hematopoietic necrosis virus. Diseases of Aquatic Organisms 15:108-114.

Roberti KA, Rohovec JS, and Winton JR. 1998. Vaccination of Rainbow Trout against Infectious Hematopoietic Necrosis (IHN) by Using Attenuated Mutants Selected by Neutralizing Monoclonal Antibodies. Journal of Aquatic Animal Health 10:328-337. doi:10.1577/1548-8667(1998)010<0328:VORTAI $>2.0 . C O ; 2$

Romero A, Dios S, Bremont M, Figueras A, and Novoa B. 2011. Interaction of the attenuated recombinant rIHNV-Gvhsv GFP virus with macrophages from rainbow trout (Oncorhynchus mykiss). Vet Immunol Immunopathol 140:119-129. 10.1016/j.vetimm.2010.12.001

Rouxel RN, Tafalla C, Merour E, Leal E, Biacchesi S, and Bremont M. 2016. Attenuated Infectious Hematopoietic Necrosis Virus with Rearranged Gene Order as Potential Vaccine. J Virol 90:10857-10866. 10.1128/jvi.01024-16

Rucker RR. 1953. A contagious disease of salmon possibly of virus origin. Washington,: U. S. Govt. Print. Off.

Saint-Jean SR, and Perez-Prieto SI. 2007. Effects of salmonid fish viruses on Mx gene expression and resistance to single or dual viral infections. Fish Shellfish Immunol 23:390-400. 10.1016/j.fsi.2006.11.012

Salonius K, Simard N, Harland R, and Ulmer JB. 2007. The road to licensure of a DNA vaccine. Curr Opin Investig Drugs 8:635-641.

Schipp M. 2012. Aquatic Animal Diseases Significant to Australia: Identification Field Guide 4th Edition. In: Australian Government Department of Agriculture FaF, Canberra, editor.

Sedegah M, Charoenvit Y, Minh L, Belmonte M, Majam VF, Abot S, Ganeshan H, Kumar S, Bacon DJ, Stowers A, Narum DL, Carucci DJ, and Rogers WO. 2004. Reduced immunogenicity of DNA vaccine plasmids in mixtures. Gene Ther 11:448-456. $10.1038 /$ sj.gt.3302139

Simon BE, and Leong JA. 2002. Gene transfer to fish cells by attenuated invasive Escherichia coli. Mar Biotechnol (NY) 4:303-309. 10.1007/s10126-002-0022-0

Suebsing R, Jeon CH, Oh MJ, and Kim JH. 2011a. Reverse transcriptase loop-mediated isothermal amplification assay for infectious hematopoietic necrosis virus in Oncorhynchus keta. Dis Aquat Organ 94:1-8. 10.3354/dao02310

Suebsing R, Kim JH, Kim SR, Park MA, and Oh MJ. 2011b. Detection of viruses in farmed rainbow trout (Oncorhynchus mykiss) in Korea by RT-LAMP assay. J Microbiol 49:741746. 10.1007/s12275-011-1209-8

Tafalla C, Rodriguez Saint-Jean S, and Perez-Prieto S. 2006. Immunological consequences of the coinfection of brown trout ( Salmo trutta) with infectious hematopoietic necrosis virus (IHNV) and infectious pancreatic necrosis virus (IPNV).

Thoulouze MI, Bouguyon E, Carpentier C, and Bremont M. 2004. Essential role of the NV protein of Novirhabdovirus for pathogenicity in rainbow trout. J Virol 78:4098-4107.

Tong G, Wei X, Yin W, Liao X, Yang K, Fang Z, Sun T, Yue Z, and Li X. 2017. Development of a Liquid Chip Technique to Simultaneously Detect Spring Viremia of Carp Virus, 
735

736

737

738

739

740

741

742

743

744

745

746

747

748

749

750

751

752

753

754

755

756

757

758

759

760

761

762

763

764

765

766

767

768

769

770

771

772

773

774

775

776

777

778

Infectious Hematopoietic Necrosis Virus, and Viral Hemorrhagic Septicemia of Salmonids. J AOAC Int 100:159-164. 10.5740/jaoacint.16-0066

Tonheim TC, Bogwald J, and Dalmo RA. 2008. What happens to the DNA vaccine in fish? A review of current knowledge. Fish Shellfish Immunol 25:1-18. 10.1016/j.fsi.2008.03.007

Traxler GS, Anderson E, LaPatra SE, Richard J, Shewmaker B, and Kurath G. 1999. Naked DNA vaccination of Atlantic salmon Salmo salar against IHNV. Dis Aquat Organ 38:183-190. 10.3354/dao038183

USDA. 2014. Vaccines aquaculture. Technical Evaluation Report Available at https://www.ams.usda.gov/sites/default/files/media/Vaccines\%20\%28Biologics\%29\%20r eport.pdf?fbclid=IwAR19hW2wVHJw3WeiaX86JwZ6tFa6LnxmUkvEaCr2iP AOWI9qtG6mI-ec02019).

van Drunen Littel-van den Hurk S, Loehr BI, and Babiuk LA. 2001. Immunization of livestock with DNA vaccines: current studies and future prospects. Vaccine 19:2474-2479.

Wade J. 2017. British Columbia farmed Atlantic Salmon health management practices. DFO Can Sci Advis Sec Res Doc:2017/2072. vi + 2055 p.

Wang B, Godillot AP, Madaio MP, Weiner DB, and Williams WV. 1998. Vaccination against pathogenic cells by DNA inoculation. Curr Top Microbiol Immunol 226:21-35.

Wang S, Zhang C, Zhang L, Li J, Huang Z, and Lu S. 2008. The relative immunogenicity of DNA vaccines delivered by the intramuscular needle injection, electroporation and gene gun methods. Vaccine 26:2100-2110. 10.1016/j.vaccine.2008.02.033

Wingfield WH, Fryer JL, and Pilcher KS. 1969. Properties of the sockeye salmon virus (Oregon strain). Proc Soc Exp Biol Med 130:1055-1059.

Winton JR. 1991. Recent advances in detection and control of infectious hematopoietic necrosis virus in aquaculture. Annual Review of Fish Diseases 1:83-93. https://doi.org/10.1016/0959-8030(91)90024-E

Woo PTK, and Cipriano RC. 2017. Fish Viruses and Bacteria: Pathobiology and Protection: CAB International, Wallingford, UK.

Woo PTK, Leatherland JF, and Bruno DW. 2011. Fish diseases and disorders: CAB International, Wallingford, UK.

Xu L, Zhao J, Liu M, Kurath G, Ren G, Lapatra SE, Yin J, Liu H, Feng J, and Lu T. 2017a. A effective DNA vaccine against diverse genotype $\mathrm{J}$ infectious hematopoietic necrosis virus strains prevalent in China. Vaccine 35:2420-2426. 10.1016/j.vaccine.2017.03.047

Xu L, Zhao J, Liu M, Ren G, Jian F, Yin J, Feng J, Liu H, and Lu T. 2017b. Bivalent DNA vaccine induces significant immune responses against infectious hematopoietic necrosis virus and infectious pancreatic necrosis virus in rainbow trout. Scientific reports 7:57005700. 10.1038/s41598-017-06143-w

Xu LM, Zhao JZ, Liu M, cao YS, Yin JS, Liu HB, and Tongyan L. 2016. High throughput screening of recombinant antibodies against infectious hematopoietic necrosis virus from a combinatorial antibody library. Aquaculture 460:32-36.

10.1016/j.aquaculture.2016.04.002

Yamamoto T, Batts WN, Arakawa CK, and Winton JR. 1990. Multiplication of Infectious Hematopoietic Necrosis Virus in Rainbow Trout following Immersion Infection: WholeBody Assay and Immunohistochemistry. Journal of Aquatic Animal Health 2:271-280. doi:10.1577/1548-8667(1990)002<0271:MOIHNV>2.3.CO;2 
779

780

781

782

783

784

785

786

787

788

789

790

791

792

793

794

795
Zhang L, Wang W, and Wang S. 2015. Effect of vaccine administration modality on immunogenicity and efficacy. Expert Rev Vaccines 14:1509-1523. $10.1586 / 14760584.2015 .1081067$

Figure Legends

\section{Figure 1:}

Infectious hematopoietic necrosis virus (IHNV) viewed under a transmission electron microscope. Any reuse of this figure is only permitted with a full citation of the original source: (Dixon et al. 2016) (Original Publisher: BioMed Central).

\section{Figure 2:}

Clinical signs of IHNV infected fishes. The infected fishes often show (A) darkening of the skin, (B) exophthalmia, and (C) petechial haemorrhages around the eyes, gills and fins. Any reuse of this figure is only permitted with a full citation of the original source: (Woo \& Cipriano 2017) (Original Publisher: CABI Publishing). 


\section{Table $\mathbf{1}$ (on next page)}

Potential antibodies, subunit, attenuated, and inactivated vaccines produced and tested for IHNV.

Binary ethylenimine (BEl); $\beta$-propiolactone (BPL); NV: non-structural protein; N:

nucleoprotein; G: glycoprotein; RPS: Relative percentage of survival; IN: intranasal delivery; IP: intraperitoneal delivery; IM: intramuscular delivery; $\mathrm{TCID}_{50}: 50 \%$ tissue culture infectious dose; $L_{50}$ : Lethal dose that kills $50 \%$ of subjects; PFU: plaque-forming unit; IFN: interferon; IHNV: infectious hematopoietic necrosis virus. 
1 Table 1: Potential antibodies, subunit, attenuated, and inactivated vaccines produced and tested for IHNV.

\begin{tabular}{|c|c|c|c|c|c|}
\hline Types of vaccines & $\begin{array}{l}\text { Agent of } \\
\text { inactivation }\end{array}$ & $\begin{array}{l}\text { Tested } \\
\text { subject }\end{array}$ & $\begin{array}{l}\text { Vaccination } \\
\text { strategy }\end{array}$ & Outcome & References \\
\hline $\begin{array}{l}\text { Purified } \\
\text { glycoprotein }\end{array}$ & - & $\begin{array}{l}\text { Rainbow } \\
\text { trout and } \\
\text { Kokanee }\end{array}$ & $\begin{array}{l}\text { Immersion } \\
\text { immunization, } \sim 50 \\
\mu \mathrm{g} / \mathrm{mL} \\
\text { glycoprotein, } 30 \\
\text { days }\end{array}$ & $\begin{array}{l}\text { Protection (RPS: } 47-83 \%) \text { against immersion challenge with } \\
\text { IHNV }\left(10^{3}-10^{6} \mathrm{TCID}_{50} / \mathrm{mL} \text { water }\right)\end{array}$ & $\begin{array}{l}\text { (Engelking \& } \\
\text { Leong 1989) }\end{array}$ \\
\hline $\begin{array}{l}\text { IHNV neutralizing } \\
\text { antibodies }\end{array}$ & $\begin{array}{l}\text { Antibodies } \\
\text { neutralization }\end{array}$ & $\begin{array}{l}\text { Rainbow } \\
\text { trout }\end{array}$ & $\begin{array}{l}\text { IP, passive } \\
\text { immunization }\end{array}$ & $\begin{array}{l}\text { Neutralizing activity produced against } 1 \text { antigenic variant } \\
\text { provided cross protection (RPS: } 89-100 \%) \text { against } \\
\text { challenged of IHNV with different antigenic variants }\left(10^{4}\right. \\
\text { PFU/mL) }\end{array}$ & $\begin{array}{l}\text { (LaPatra et al. } \\
\text { 1994) }\end{array}$ \\
\hline $\begin{array}{l}\text { Neutralizing } \\
\text { monoclonal } \\
\text { antibody-selected } \\
\text { attenuated IHNV } \\
\text { mutants }\end{array}$ & $\begin{array}{l}\text { Monoclonal } \\
\text { antibodies } \\
\text { neutralization }\end{array}$ & $\begin{array}{l}\text { Rainbow } \\
\text { trout and } \\
\text { Kokanee }\end{array}$ & $\begin{array}{l}\text { Immersion } \\
\text { immunization, } 10^{4} \text { - } \\
10^{5} \mathrm{TCID}_{50} / \mathrm{mL}, 24 \\
\text { h }\end{array}$ & $\begin{array}{l}\text { Protection (RPS: } 12 \%-65 \%) \text { against wild type virus }\left(10^{5}\right. \\
\left.\text { TCID }_{50} / \mathrm{mL}\right)\end{array}$ & $\begin{array}{l}\text { (Roberti et al. } \\
\text { 1998) }\end{array}$ \\
\hline $\begin{array}{l}\text { Escherichia coli } \\
\text { expressed } \\
\text { nucleoprotein and }\end{array}$ & - & $\begin{array}{l}\text { Rainbow } \\
\text { trout }\end{array}$ & $\begin{array}{l}\text { Immersion, } \\
\text { bacterial lysate ( } 3 \\
\mathrm{mg} / \mathrm{mL})\end{array}$ & $\begin{array}{l}\text { Cross protection (RPS: } 38-64 \%) \text { against } 3 \text { strains of IHNV } \\
\text { challenge }\left(10^{3}-10^{4} \mathrm{TCID}_{50} / \mathrm{mL}\right)\end{array}$ & (Oberg et al. 1991) \\
\hline
\end{tabular}




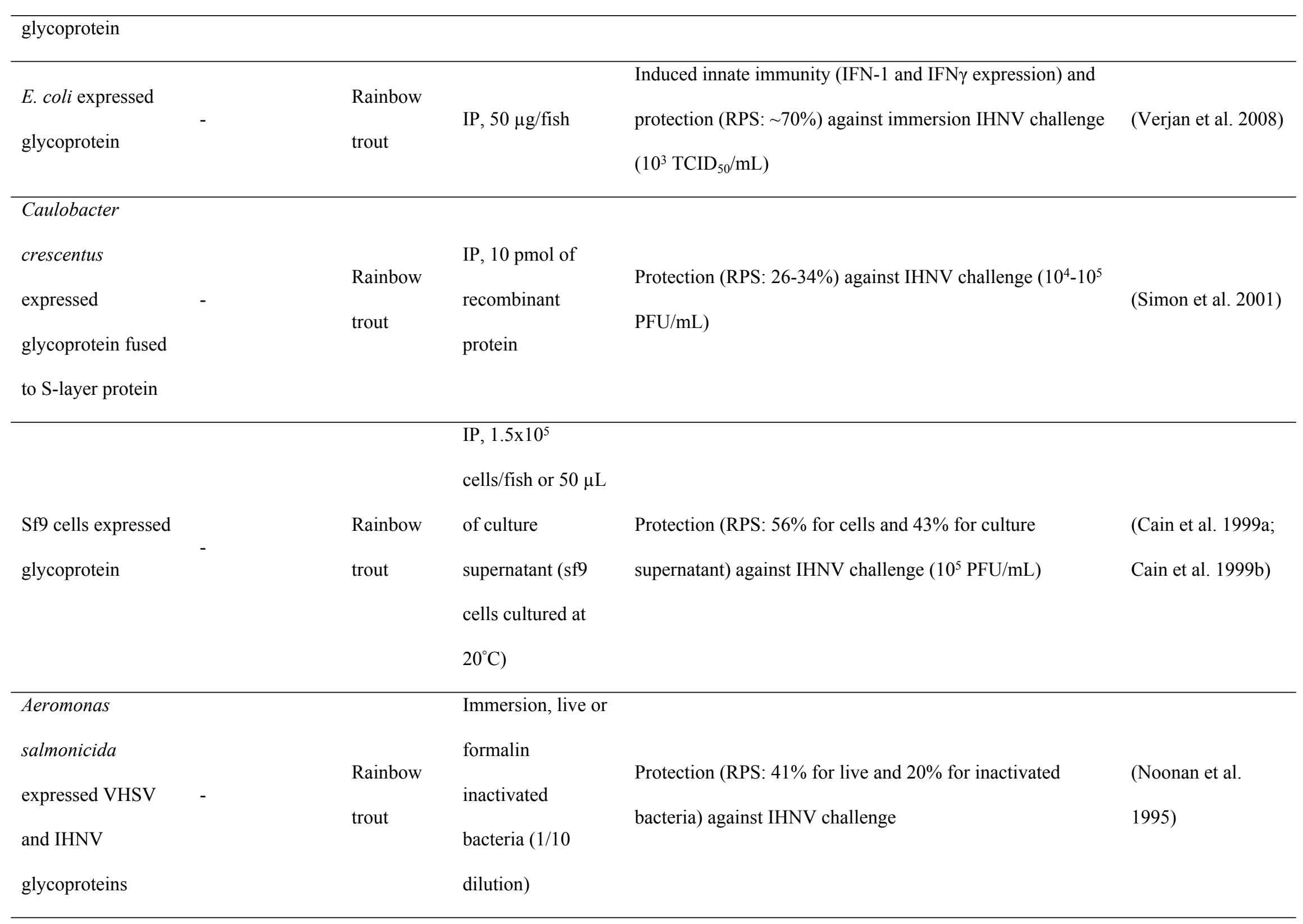




\begin{tabular}{|c|c|c|c|c|c|}
\hline $\begin{array}{l}\text { E. coli expressed } \\
\text { glycoprotein } \\
\text { (IHNV-G-GST) }\end{array}$ & - & $\begin{array}{l}\text { Rainbow } \\
\text { trout }\end{array}$ & $\mathrm{IP}, 10 \mu \mathrm{g} /$ fish & $\begin{array}{l}\text { Specific antibody against IHNV that can transfer from } \\
\text { mother fish to fry and protect (RPS: } 50 \%) \text { against IHNV } \\
\left(10^{6} \mathrm{PFU} / \mathrm{mL}\right)\end{array}$ & $\begin{array}{l}\text { (Oshima et al. } \\
\text { 1996) }\end{array}$ \\
\hline $\begin{array}{l}\text { E. coli and yeast- } \\
\text { derived } \\
\text { glycoprotein by } \\
\text { yeast surface } \\
\text { display technology }\end{array}$ & - & $\begin{array}{l}\text { Rainbow } \\
\text { trout }\end{array}$ & $\begin{array}{l}\text { Oral, } 1.6 \times 10^{9} \text { yeast } \\
\text { cells }\end{array}$ & $\begin{array}{l}\text { Protection (RPS: } 45.8 \%) \text { against IHNV }\left(10^{2} \mathrm{PFU} / \mathrm{mL}\right) \text { via } \\
\text { activation of adaptive immunity including upregulation of } \\
\text { IgM B cells, helper T cells and cytotoxic T cells; production } \\
\text { of specific antibodies; and promotion of antiviral genes } \\
\text { expression (IFN-1, Mx-1) }\end{array}$ & $\begin{array}{l}\text { (Zhao et al. 2016; } \\
\text { Zhao et al. 2017) }\end{array}$ \\
\hline \multirow[t]{2}{*}{$\begin{array}{l}\text { Attenuated reverse } \\
\text { genetic IHNV }\end{array}$} & $\begin{array}{l}\text { Removal of } \\
\text { non-structural } \\
(\mathrm{NV}) \text { protein or } \\
\text { exchange to } \\
\text { viral } \\
\text { hemorrhagic } \\
\text { septicaemia } \\
\text { virus } \\
\text { glycoprotein }\end{array}$ & $\begin{array}{l}\text { Rainbow } \\
\text { trout }\end{array}$ & $\mathrm{IP}, 10^{6} \mathrm{PFU} / \mathrm{mL}$ & $\begin{array}{l}\mathrm{NV} \text { protein promotes nitric oxide and reactive oxygen } \\
\text { species production by macrophages which help to protect } \\
\text { against the infection }\end{array}$ & $\begin{array}{l}\text { (Romero et al. } \\
\text { 2008) }\end{array}$ \\
\hline & $\begin{array}{l}\text { Modified } \\
\text { nucleoprotein } \\
\text { (N) and }\end{array}$ & $\begin{array}{l}\text { Rainbow } \\
\text { trout }\end{array}$ & $\begin{array}{l}\text { Immersion, } 5 \times 10^{4} \\
\mathrm{PFU} / \mathrm{mL}\end{array}$ & $\begin{array}{l}\text { Different modifications of } N \text { and } G \text { gene sequences resulted } \\
\text { in different protection efficacy against IHNV infection. } \\
\text { N2G3 strains provided the best protection (RPS: 86\%) }\end{array}$ & $\begin{array}{l}\text { (Rouxel et al. } \\
\text { 2016) }\end{array}$ \\
\hline
\end{tabular}




\begin{tabular}{|c|c|c|c|c|c|}
\hline & $\begin{array}{l}\text { glycoprotein }(\mathrm{G}) \\
\text { sequence }\end{array}$ & & & $\begin{array}{l}\text { against IHNV }\left(5 \times 10^{4} \mathrm{PFU} / \mathrm{mL}\right) \text { through activation of } \\
\text { specific antibody and antiviral system (IFN-1). }\end{array}$ & \\
\hline $\begin{array}{l}\text { Synthetic peptides } \\
\text { P76, P226, P268 }\end{array}$ & - & $\begin{array}{l}\text { Rainbow } \\
\text { trout }\end{array}$ & $\mathrm{IP}, 1 \mathrm{mg} /$ fish & $\begin{array}{l}\text { Specific antibody against IHNV but inconsistent, no } \\
\text { challenge trial }\end{array}$ & $\begin{array}{l}\text { (Emmenegger et al. } \\
\text { 1997) }\end{array}$ \\
\hline $\begin{array}{l}\text { Infectious } \\
\text { pancreatic necrosis } \\
\text { virus }\end{array}$ & - & $\begin{array}{l}\text { Rainbow } \\
\text { trout }\end{array}$ & $\mathrm{IP}, 10^{6.3} \mathrm{TCID}_{50}$ & Protection (RPS: $68.8 \%)$ against IHNV $\left(10^{5} \mathrm{TCID}_{50}\right)$ & (Kim 2009) \\
\hline $\begin{array}{l}\text { Polyinosinic } \\
\text { polycytidylic acid } \\
\text { [Poly(I:C)] }\end{array}$ & - & $\begin{array}{l}\text { Rainbow } \\
\text { trout }\end{array}$ & IP, $50 \mu \mathrm{g} /$ fish & Protection (RPS: $95.2 \%)$ against IHNV $\left(10^{5} \mathrm{TCID}_{50}\right)$ & (Kim 2009) \\
\hline \multirow[t]{2}{*}{$\begin{array}{l}\text { Inactivated } \\
\text { vaccines }\end{array}$} & $\begin{array}{l}\text { Binary } \\
\text { ethylenimine } \\
\text { (BEI), } \beta \text { - } \\
\text { propiolactone } \\
\text { (BPL), } \\
\text { formaldehyde }\end{array}$ & $\begin{array}{l}\text { Rainbow } \\
\text { trout }\end{array}$ & $\begin{array}{l}\text { IP, } 8 \times 10^{5.82} \\
\text { TCID }_{50}\end{array}$ & $\begin{array}{l}\text { Induced specific IgM in serum and mucus (skin surface and } \\
\text { gills); BPL inactivated vaccine }>\text { PEI inactivated vaccine }> \\
\text { formaldehyde inactivated vaccine } \\
\text { Protection against IP IHNV challenge }\left(10 \times 10^{3.36} \mathrm{LD}_{50}\right) \text {; BPL } \\
\text { inactivated vaccine (RPS: } 91.67 \%)>\text { PEI inactivated } \\
\text { vaccine (RPS: } 83.33 \%)>\text { formaldehyde inactivated vaccine } \\
\text { (RPS: } 79.17 \%)\end{array}$ & (Tang et al. 2016) \\
\hline & $\begin{array}{l}\text { BEI, BPL, } \\
\text { formaldehyde, } \\
\text { heat }\end{array}$ & $\begin{array}{l}\text { Rainbow } \\
\text { trout }\end{array}$ & $\begin{array}{l}\text { IP and IM, } 10^{7.5} \\
\operatorname{TCID}_{50}\end{array}$ & $\begin{array}{l}\text { BPL inactivated vaccine induced consistent protection } \\
\text { against IP IHNV challenge }\left(10^{5} \mathrm{PFU} / \mathrm{mL}\right)\end{array}$ & $\begin{array}{l}\text { (Anderson et al. } \\
\text { 2008) }\end{array}$ \\
\hline
\end{tabular}




\begin{tabular}{|c|c|c|c|c|c|}
\hline & & $\begin{array}{l}\text { Rainbow } \\
\text { trout }\end{array}$ & $\begin{array}{l}\left.\text { IP, } 10^{5} \text { (day } 0\right) ; 10^{7} \\
\left(2 \text { months); } 2 \times 10^{7}\right. \\
\text { (4 months) }\end{array}$ & Production of specific antibody & $\begin{array}{l}\text { (Ristow et al. } \\
\text { 2000) }\end{array}$ \\
\hline Attenuated IHNV & $\begin{array}{l}\text { Tissue culture } \\
\text { passage } 100 x\end{array}$ & $\begin{array}{l}\text { Rainbow } \\
\text { trout }\end{array}$ & $\begin{array}{l}\text { IN and IM, } 10^{6} \\
\text { PFU } / \mathrm{mL}\end{array}$ & $\begin{array}{l}\text { IN provided comparable protection against IM vaccination; } \\
\text { live IHNV challenged (5-10,000 } \mathrm{PFU} / \mathrm{mL} \text { ) through } \\
\text { activation of nasopharynx-associated lymphoid tissue } \mathrm{IgT}^{+} \\
\text {B cells without causing damage to central nervous system }\end{array}$ & $\begin{array}{l}\text { (LaPatra et al. } \\
\text { 2015; Larragoite et } \\
\text { al. 2016; Salinas et } \\
\text { al. 2015; Tacchi et } \\
\text { al. 2014) }\end{array}$ \\
\hline
\end{tabular}

2 Notes:

3 Binary ethylenimine (BEI); $\beta$-propiolactone (BPL); NV: non-structural protein; N: nucleoprotein; G: glycoprotein; RPS: Relative 4 percentage of survival; IN: intranasal delivery; IP: intraperitoneal delivery; IM: intramuscular delivery; TCID $_{50}: 50 \%$ tissue culture 5 infectious dose; $\mathrm{LD}_{50}$ : Lethal dose that kills $50 \%$ of subjects; PFU: plaque-forming unit; IFN: interferon; IHNV: infectious 6 hematopoietic necrosis virus. 


\section{Table 2 (on next page)}

Potential DNA vaccines produced and tested for IHNV.

P: phosphoprotein; M: matrix protein; NV: non-structural protein; N: nucleoprotein; G:

glycoprotein; VP2; viral protein 2; VP3: viral protein 3; RPS: relative percentage of survival; CM: cumulative percentage mortality; IP: intraperitoneal delivery; IM: intramuscular delivery; IB: intrabuccal delivery; GG: gene gun delivery; SS: scarification of skin; TCID $_{50}$ : $50 \%$ tissue culture infectious dose; IRF1A: interferon regulatory factor $1 A$; PFU: plaque-forming unit; IHNV: infectious hematopoietic necrosis virus ; SHRV: snakehead rhabdovirus; SVCV: spring viremia of carp virus; VHSV: viral hemorrhagic septicemia virus; IPNV: infectious pancreatic necrosis virus. 
1 Table 2: Potential DNA vaccines produced and tested for IHNV.

\begin{tabular}{|c|c|c|c|c|}
\hline Immunogens & $\begin{array}{l}\text { Tested } \\
\text { subject }\end{array}$ & $\begin{array}{l}\text { Vaccination } \\
\text { strategy }\end{array}$ & Outcome & References \\
\hline $\begin{array}{l}\text { DNA encoding G } \\
\text { protein of IHNV }\end{array}$ & $\begin{array}{l}\text { Rainbow } \\
\text { trout }\end{array}$ & $\mathrm{IM}, 100 \mathrm{ng}$ & $\begin{array}{l}\left.\text { Protection against IHNV immersion ( } 10^{5} \mathrm{PFU} / \mathrm{mL}\right) \\
\text { challenges at } 4 \text { (RPS: } 91.5 \%) \text {, and } 7 \text { (RPS: } 93.5 \%) \text { days } \\
\text { post-vaccination, and IHNV IP }\left(10^{2} \text { PFU in } 50 \mu \mathrm{L}\right) \\
\text { challenges at } 28 \text { (RPS: } 91.5 \%), 120 \text { (RPS: } 86.5 \%) \text { and } 180 \\
\text { (RPS: } 70 \% \text { ) days post-vaccination }\end{array}$ & 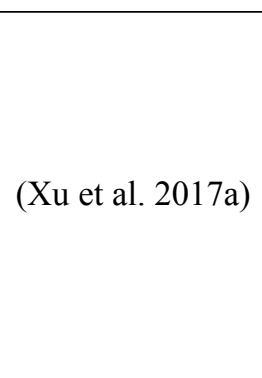 \\
\hline $\begin{array}{l}\text { DNA encoding G } \\
\text { protein of IHNV }\end{array}$ & $\begin{array}{l}\text { Rainbow } \\
\text { trout }\end{array}$ & IM, 1-100 ng & $\begin{array}{l}\text { DNA vaccine dose of } 1 \text { to } 10 \mathrm{ng} \text { conferred significant } \\
\text { protections to the immunized fishes against IHNV IP } \\
\text { challenge, and higher dose of DNA vaccine ( } 100 \mathrm{ng}) \\
\text { improved protection against a broad range of viral strains }\end{array}$ & $\begin{array}{l}\text { (Lapatra et al. } \\
\text { 2002) }\end{array}$ \\
\hline $\begin{array}{l}\text { DNA encoding G } \\
\text { protein of IHNV }\end{array}$ & $\begin{array}{l}\text { Rainbow } \\
\text { trout }\end{array}$ & $\mathrm{IM}, 10 \mu \mathrm{g}$ & $\begin{array}{l}\left.\text { Protection against IHNV immersion ( } 10^{5} \mathrm{PFU} / \mathrm{mL}\right) \\
\text { challenges at } 30 \text { (RPS: } 93 \% \text { ), and } 70 \text { (RPS: } 87 \% \text { ) days } \\
\text { post-vaccination }\end{array}$ & (Kim et al. 2000) \\
\hline $\begin{array}{l}\text { DNA encoding G } \\
\text { protein of IHNV }\end{array}$ & $\begin{array}{l}\text { Rainbow } \\
\text { trout }\end{array}$ & $\mathrm{IM}, 1 \mu \mathrm{g}$ & $\begin{array}{l}\text { Protection against IHNV immersion }\left(10^{4} \mathrm{PFU} / \mathrm{mL}\right) \\
\text { challenge at } 7 \text { days post-vaccination (CM: } 2 \%) \text {. When the } \\
\text { immunized fishes were challenged with higher dose }\left(10^{5}\right. \\
\text { PFU } / \mathrm{mL}) \text { at } 1-2 \text { days post-vaccination, no significant }\end{array}$ & $\begin{array}{l}\text { (LaPatra et al. } \\
\text { 2001) }\end{array}$ \\
\hline
\end{tabular}




\begin{tabular}{|c|c|c|c|c|}
\hline & & & $\begin{array}{l}\text { protection was observed. However, the immunized fishes } \\
\text { were partially protected }(\mathrm{CM}: \approx 41 \% \text { ) when they were } \\
\text { challenged at } 4 \text { days post-vaccination, and significantly } \\
\text { protected when they were challenged at } 7 \text { days post- } \\
\text { vaccination }(\mathrm{CM}: 20 \%)\end{array}$ & \\
\hline $\begin{array}{l}\text { DNA encoding G } \\
\text { protein of IHNV }\end{array}$ & $\begin{array}{l}\text { Rainbow } \\
\text { trout }\end{array}$ & $\mathrm{IM}, 1 \mu \mathrm{g}$ & $\begin{array}{l}\text { Protection against IHNV immersion }\left(10^{5} \mathrm{PFU} / \mathrm{mL}\right) \\
\text { challenge at } 18 \text { days post-vaccination (CM: } 18 \%)\end{array}$ & $\begin{array}{l}\text { (Lorenzen et al. } \\
\text { 2002b) }\end{array}$ \\
\hline $\begin{array}{l}\text { DNA encoding G } \\
\text { protein of IHNV }\end{array}$ & $\begin{array}{l}\text { Rainbow } \\
\text { trout }\end{array}$ & $\begin{array}{l}\text { IM, IP, IB, GG, SS, } \\
100 \mathrm{ng} \\
\text { Immersion } \\
\text { treatment- water } \\
\text { containing } 3.4 \times 10^{6} \\
\text { DNA-coated } \\
\text { magnetic } \\
\text { polystyrene beads } \\
\text { (10 mg of beads } \\
\text { total weight). } \\
\text { Concentration of } \\
\text { DNA coated per mg }\end{array}$ & $\begin{array}{l}\text { Fishes immunized via IM, IP and GG route were protected } \\
\text { (RPS: } 100 \%, 50.3 \% \text { and } 96.2 \% \text { respectively) from IHNV } \\
\text { immersion ( } 2.8 \times 10^{4} \mathrm{PFU} / \mathrm{mL} \text { ) challenges at } 29 \text { days post- } \\
\text { vaccination. Vaccination via other routes did not induce } \\
\text { significant protection against IHNV challenges }\end{array}$ & $\begin{array}{l}\text { (Corbeil et al. } \\
\text { 2000a) }\end{array}$ \\
\hline
\end{tabular}




\begin{tabular}{|c|c|c|c|c|}
\hline & & $\begin{array}{l}\text { beads weight was } \\
60 \mu \mathrm{g}\end{array}$ & & \\
\hline $\begin{array}{l}\text { DNA encoding G } \\
\text { protein of IHNV }\end{array}$ & $\begin{array}{l}\text { Rainbow } \\
\text { trout }\end{array}$ & $\mathrm{IM}, 0.001-5 \mu \mathrm{g}$ & $\begin{array}{l}\text { Strong protection }(\mathrm{CM}<6 \%) \text { against homologous IHNV } \\
\text { immersion challenges }\left(10^{1}-10^{4} \mathrm{PFU} / \mathrm{mL}\right) \text { was observed in } \\
\text { fishes immunized with DNA vaccine of various doses ( } 0.1 \text { - } \\
5 \mu \mathrm{g}) \text {. Significant protection }(\mathrm{CM}: 18 \%) \text { was also induced } \\
\text { in fishes immunized with DNA vaccine of as low as } 0.001 \\
\mu \mathrm{g} \text {. } \\
\text { Fishes immunized with } 0.1 \mu \mathrm{g} \text { DNA vaccine were } \\
\text { significantly protected from heterologous challenges } \\
\text { including WRAC, RB-1, AK-14, 220-90, Shizuoka and 32- } \\
87 \text { strains but not the Col-85 strain. }\end{array}$ & 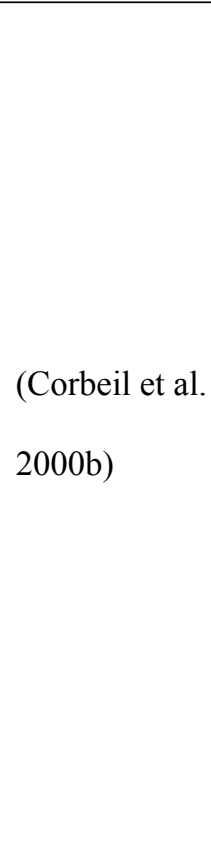 \\
\hline $\begin{array}{l}\text { DNA encoding G } \\
\text { protein of IHNV }\end{array}$ & $\begin{array}{l}\text { Rainbow } \\
\text { trout }\end{array}$ & $\mathrm{IM}, 100 \mathrm{ng}$ or $50 \mu \mathrm{g}$ & $\begin{array}{l}\text { Expression of G protein was detected in muscle, kidney, } \\
\text { and thymus tissues, with levels peaking at } 14 \text { days and } \\
\text { becoming undetectable by } 28 \text { days. No vaccine-specific } \\
\text { pathological damage at the dose of } 100 \text { ng DNA per fish. } \\
\text { Increased inflammatory response was observed when } 50 \mu \mathrm{g} \\
\text { DNA was administered. }\end{array}$ & $\begin{array}{l}\text { (Garver et al. } \\
\text { 2005a) }\end{array}$ \\
\hline DNA encoding $\mathrm{G}$ & Chinook & $\mathrm{IM}, 0.1$ or $1 \mu \mathrm{g}$ & DNA encoding G protein of IHNV protected Chinook and & (Garver et al. \\
\hline
\end{tabular}




\begin{tabular}{|c|c|c|c|c|}
\hline protein of IHNV & $\begin{array}{l}\text { salmon, } \\
\text { sockeye } \\
\text { salmon, } \\
\text { kokanee } \\
\text { salmon, } \\
\text { rainbow } \\
\text { trout }\end{array}$ & & $\begin{array}{l}\text { sockeye/kokanee salmon against IHNV immersion or IP } \\
\text { challenge (RPS: } 23-86 \% \text { ) under variety of conditions but } \\
\text { immunized rainbow trout was better protected (RPS: } \\
100 \%)\end{array}$ & 2005b) \\
\hline $\begin{array}{l}\text { DNA encoding G } \\
\text { protein of IHNV }\end{array}$ & $\begin{array}{l}\text { Rainbow } \\
\text { trout }\end{array}$ & $\mathrm{IM}, 0.1-25 \mu \mathrm{g}$ & $\begin{array}{l}\text { DNA vaccine dose of } 1 \mu \mathrm{g} \text { and above conferred complete } \\
\text { protection to immunized fishes against IHNV IP }\left(10^{6} \mathrm{PFU}\right. \\
\text { per fish) challenge at } 6 \text { weeks post-vaccination }\end{array}$ & $\begin{array}{l}\text { (LaPatra et al. } \\
\text { 2000) }\end{array}$ \\
\hline $\begin{array}{l}\text { DNA encoding G } \\
\text { protein of IHNV }\end{array}$ & $\begin{array}{l}\text { Atlantic } \\
\text { salmon, } \\
\text { Rainbow } \\
\text { trout }\end{array}$ & $\mathrm{IM}, 25 \mu \mathrm{g}$ & $\begin{array}{l}\text { Complete protection (RPS: } 90-100 \% \text { ) against IHNV } \\
\text { cohabitation (healthy fishes cohabitated with fishes } \\
\text { injected with } 4.9 \times 10^{3} \mathrm{PFU} \text { per fish) and immersion ( } 4.6 \\
\text { X } 10^{3} \mathrm{PFU} \text { challenges at } 8 \text { weeks post-vaccination. Passive } \\
\text { immunization of rainbow trout with immune serum from } \\
\text { the immunized Atlantic salmon conferred significant } \\
\text { protection against IHNV immersion challenge }\end{array}$ & $\begin{array}{l}\text { (Traxler et al. } \\
\text { 1999) }\end{array}$ \\
\hline $\begin{array}{l}\text { DNA encoding G } \\
\text { protein of IHNV }\end{array}$ & $\begin{array}{l}\text { Rainbow } \\
\text { trout }\end{array}$ & $\mathrm{IM}, 0.1 \mu \mathrm{g}$ & $\begin{array}{l}\text { Complete protection against IHNV IP }\left(10^{3}-10^{8} \text { PFU per }\right. \\
\text { fish) challenges in vaccinated fishes at } 3 \text { months post- }\end{array}$ & (Kurath et al. 2006) \\
\hline
\end{tabular}




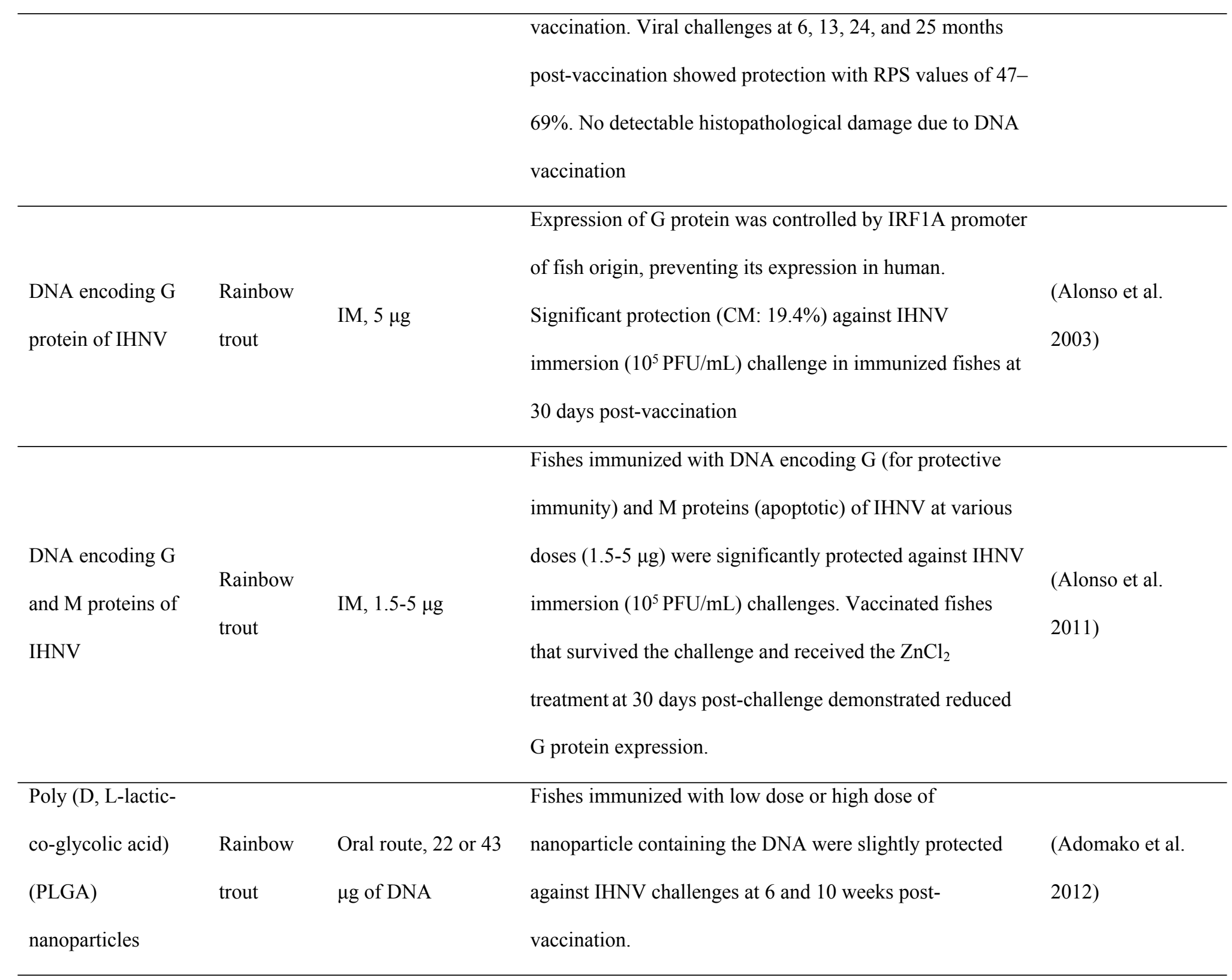




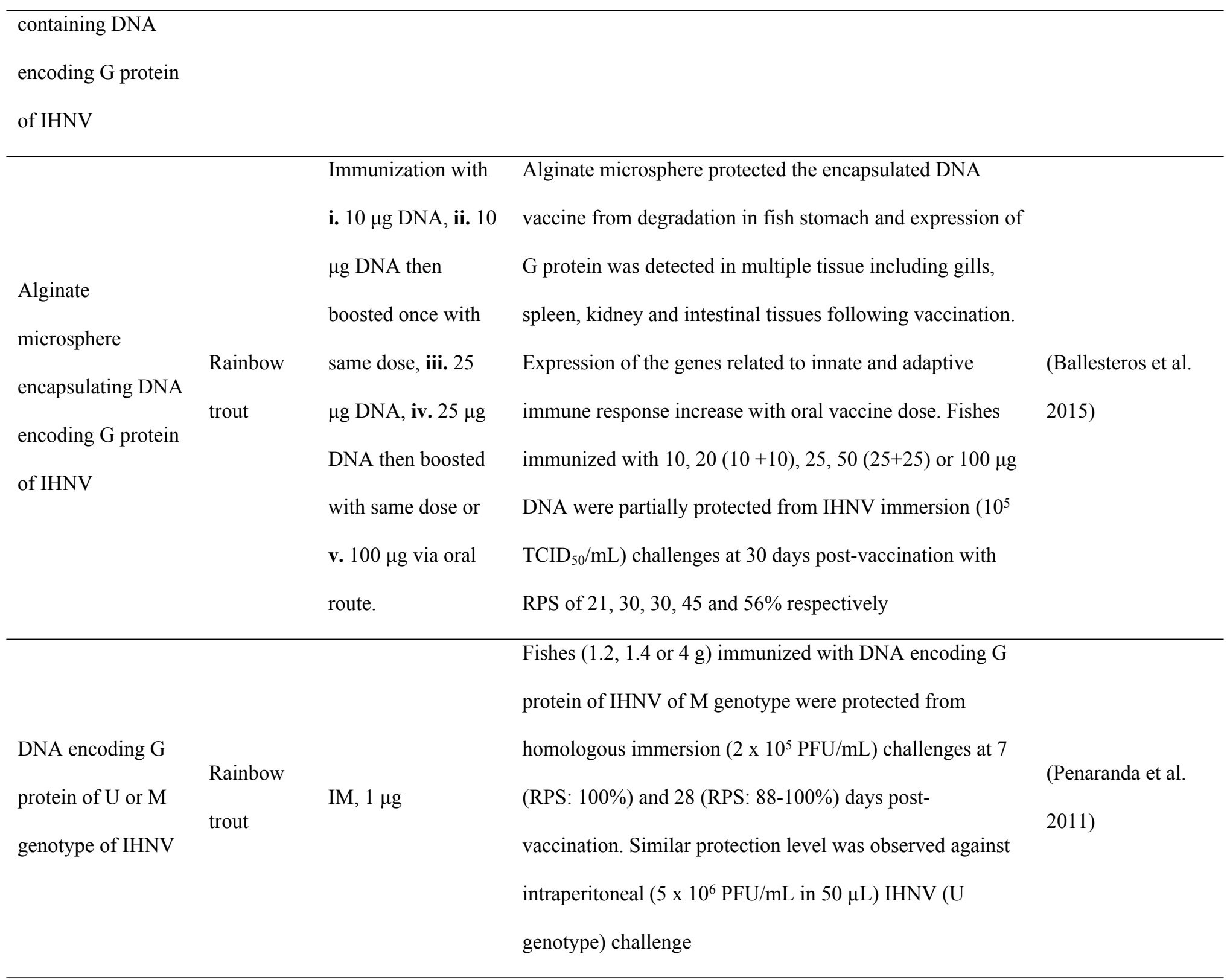


Fishes immunized with DNA encoding G protein of IHNV

of $\mathrm{U}$ genotype were protected from homologous

intraperitoneal $\left(5 \times 10^{6} \mathrm{PFU} / \mathrm{mL}\right.$ in $\left.50 \mu \mathrm{L}\right)$ challenges at 7

(RPS: 86\%) and 28 (RPS: 96\%) days post-vaccination.

Similar high protection level against immersion $\left(2 \times 10^{5}\right.$

PFU $/ \mathrm{mL}$ ) IHNV (M genotype) challenge was observed in

bigger fishes ( $4 \mathrm{~g})$ but not juvenile fishes (1.2 $\mathrm{g}$ )

Partial protection against IHNV immersion $\left(10^{4} \mathrm{PFU} / \mathrm{mL}\right)$

$\begin{array}{lll}\text { DNA encoding N } & \text { Rainbow } & \\ \text { protein of IHNV } & \text { trout } & \text { IM, } 1 \mu \mathrm{g}\end{array}$

challenge at 28 days post-vaccination $(\mathrm{CM}: \approx 38 \%)$. When

the immunized fishes were challenged with higher dose

(LaPatra et al.

$\left(10^{5} \mathrm{PFU} / \mathrm{mL}\right)$ at time points shorter than 1 week, no

significant protection was observed

Rainbow trout fry immunized with DNA encoding G

protein at all doses were protected from immersion $\left(10^{5}\right.$

PFU/mL) IHNV challenge (CM: 0-2\%) at 4 to 6 weeks

post-vaccination. Protection against IHNV reduced when

(Corbeil et al.

trout, for rainbow trout.

sockeye $\quad 25 \mu \mathrm{g}$ for sockeye

salmon salmon.

these fishes were challenged with IHNV (IP, $10^{6} \mathrm{PFU} / \mathrm{mL}$

1999)

in $100 \mu \mathrm{L})$ at $58(\mathrm{CM}: 31 \%)$ and $80(\mathrm{CM}: 49 \%)$ days-

vaccination. DNA encoding other proteins induced no 
significant protections throughout the experiment

Passive immunization with immune sera from sockyeye

salmon immunized with DNA encoding G protein

protected rainbow trout against IHNV immersion $(10$

PFU/mL) challenge (RPS: 100\%)

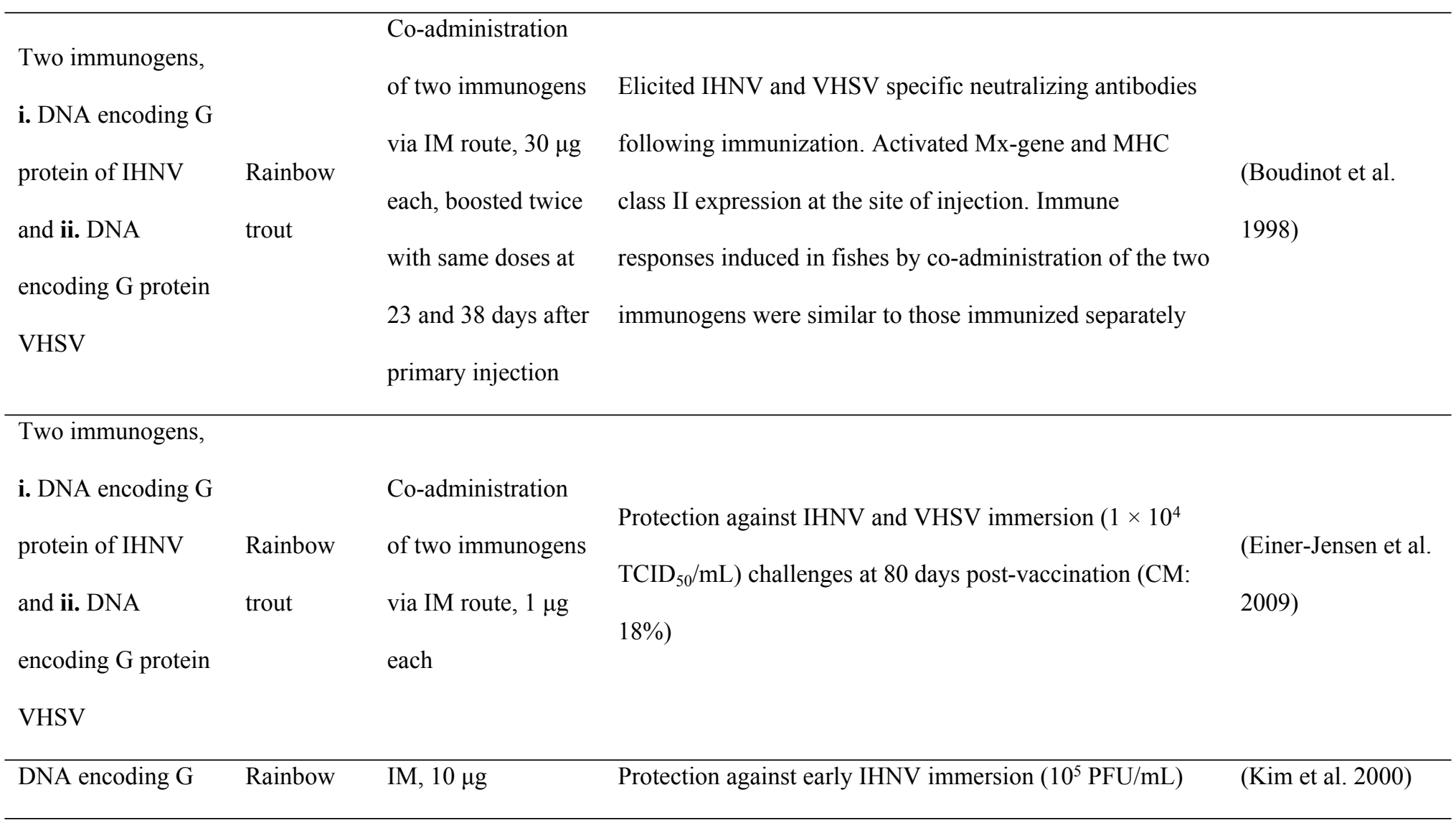




\begin{tabular}{|c|c|c|c|c|}
\hline protein of SHRV & trout & & $\begin{array}{l}\text { challenge at } 30 \text { (RPS: 98\%) days post-vaccination but not } \\
\text { late immersion challenge at } 70 \text { (RPS: } 26 \% \text { ) days post- } \\
\text { vaccination }\end{array}$ & \\
\hline $\begin{array}{l}\text { DNA encoding G } \\
\text { protein of SVCV }\end{array}$ & $\begin{array}{l}\text { Rainbow } \\
\text { trout }\end{array}$ & $\mathrm{IM}, 10 \mu \mathrm{g}$ & $\begin{array}{l}\text { Protection against early IHNV immersion }\left(10^{5} \mathrm{PFU} / \mathrm{mL}\right) \\
\text { challenge at } 30 \text { (RPS: } 95 \%) \text { days post-vaccination but not } \\
\text { late immersion challenge at } 70 \text { (RPS: } 17 \%) \text { days post- } \\
\text { vaccination }\end{array}$ & 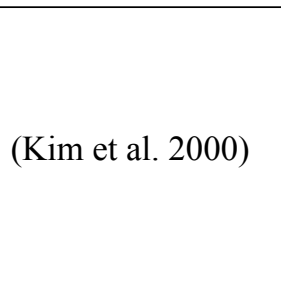 \\
\hline $\begin{array}{l}\text { DNA encoding } \\
\text { VP2 of IPNV }\end{array}$ & - & - & $\begin{array}{l}\text { BF-2 cells transfected with plasmid encoding VP2 induces } \\
\text { an antiviral state against IPNV and IHNV infection }\end{array}$ & $\begin{array}{l}\text { (de Las Heras et al. } \\
\text { 2009) }\end{array}$ \\
\hline $\begin{array}{l}\text { DNA encoding G } \\
\text { protein of VHSV }\end{array}$ & $\begin{array}{l}\text { Rainbow } \\
\text { trout }\end{array}$ & $\mathrm{IM}, 1 \mu \mathrm{g}$ & $\begin{array}{l}\text { Protection against IHNV immersion }\left(10^{4} \mathrm{PFU} / \mathrm{mL}\right) \\
\text { challenges at } 4,7 \text { and } 14(\mathrm{CM}: 0-10 \%) \text { days post- } \\
\text { vaccination but not immersion challenge at } 28(\mathrm{CM} \text { : } \\
\approx 69 \%) \text { days post-vaccination }\end{array}$ & $\begin{array}{l}\text { (LaPatra et al. } \\
\text { 2001) }\end{array}$ \\
\hline $\begin{array}{l}\text { DNA encoding G } \\
\text { protein of VHSV }\end{array}$ & $\begin{array}{l}\text { Rainbow } \\
\text { trout }\end{array}$ & $\mathrm{IM}, 1 \mu \mathrm{g}$ & $\begin{array}{l}\text { Protection against IHNV immersion }\left(10^{5} \mathrm{PFU} / \mathrm{mL}\right) \\
\text { challenge at } 18 \text { days post-vaccination }(\mathrm{CM}: 13 \%)\end{array}$ & $\begin{array}{l}\text { (Lorenzen et al. } \\
2002 b)\end{array}$ \\
\hline $\begin{array}{l}\text { DNA encoding } G \\
\text { protein of rabies } \\
\text { virus. }\end{array}$ & $\begin{array}{l}\text { Rainbow } \\
\text { trout }\end{array}$ & $\mathrm{IM}, 1 \mu \mathrm{g}$ & $\begin{array}{l}\text { No protection against IHNV immersion }\left(10^{4} \mathrm{PFU} / \mathrm{mL}\right) \\
\text { challenge }\end{array}$ & $\begin{array}{l}\text { (LaPatra et al. } \\
\text { 2001) }\end{array}$ \\
\hline $\begin{array}{l}\text { DNA encoding } \mathrm{G} \\
\text { protein of IHNV }\end{array}$ & $\begin{array}{l}\text { Rainbow } \\
\text { trout }\end{array}$ & $\mathrm{IM}, 1 \mu \mathrm{g}$ & $\begin{array}{l}\text { Protection against IHNV IP }\left(10^{2} \mathrm{PFU} / \mathrm{mL} \text { in } 100 \mu \mathrm{L}\right) \\
\text { challenges at } 30 \text { (RPS: } 93.3 \%) \text {, and } 60 \text { (RPS: } 89.4 \%) \text { days }\end{array}$ & (Xu et al. 2017b) \\
\hline
\end{tabular}


and VP2-VP3 gene

of IPNV post-vaccination. Protection against simultaneous IHNV

and IPNV IP $\left(10^{2}\right.$ and $10^{6} \mathrm{PFU} / \mathrm{mL}$ in $\left.100 \mu \mathrm{L}\right)$ challenges

at 30 (RPS: 86.7\%), and 60 (RPS: 92.3\%) days post-

vaccination

2 Notes:

3

4

5

6 IRF1A: interferon regulatory factor 1A; PFU: plaque-forming unit; IHNV: infectious hematopoietic necrosis virus; SHRV: snakehead

7 rhabdovirus; SVCV: spring viremia of carp virus; VHSV: viral hemorrhagic septicemia virus; IPNV: infectious pancreatic necrosis

8 virus. 


\section{Figure 1}

Infectious hematopoietic necrosis virus (IHNV) viewed under a transmission electron microscope.

Any reuse of this figure is only permitted with a full citation of the original source: (Dixon et al. 2016) (Original Publisher: BioMed Central).

*Note: Auto Gamma Correction was used for the image. This only affects the reviewing manuscript. See original source image if needed for review. 


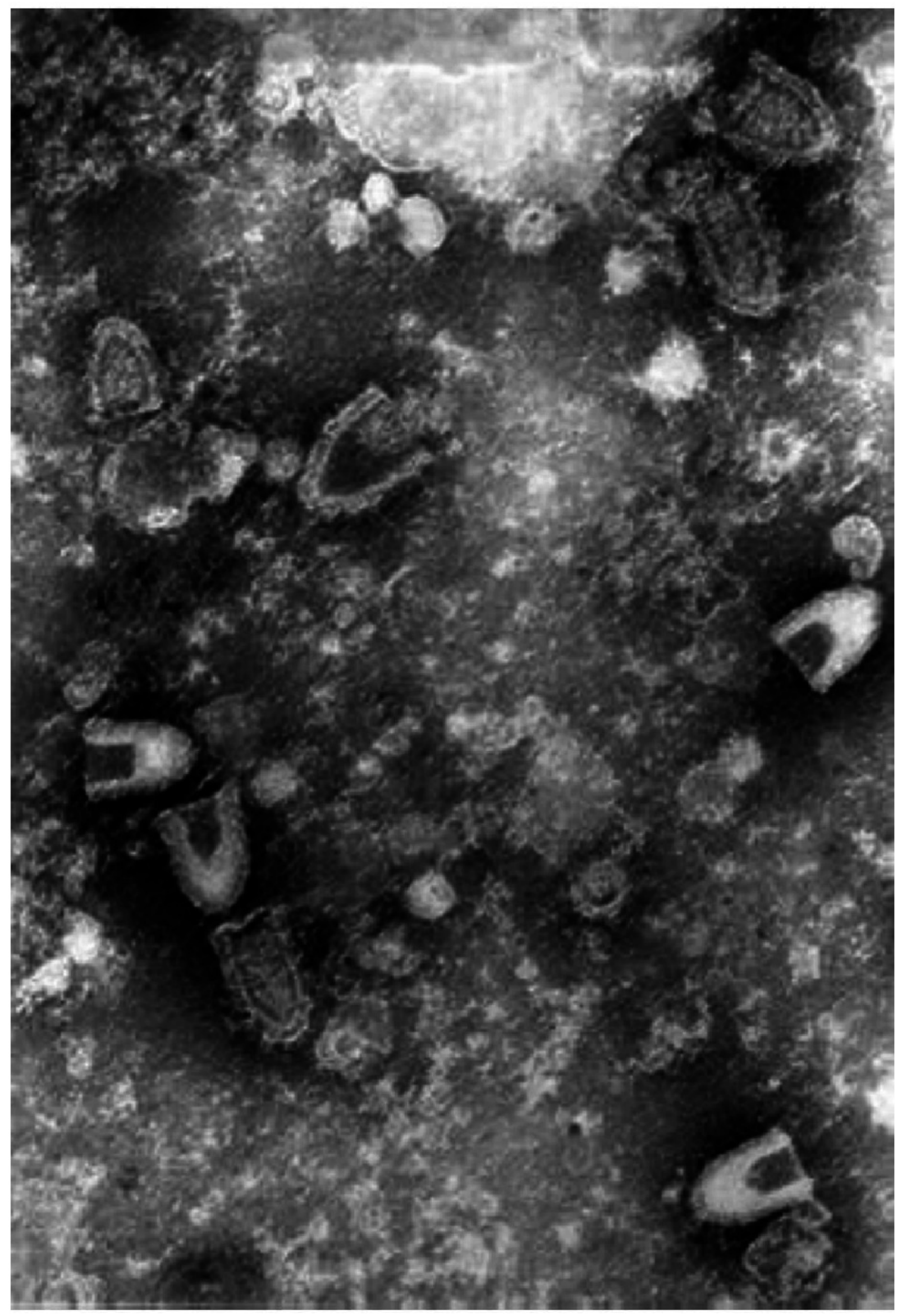




\section{Figure 2}

Clinical signs of IHNV infected fishes.

The infected fishes often show (A) darkening of the skin, (B) exophthalmia, and (C) petechial haemorrhages around the eyes, gills and fins. Any reuse of this figure is only permitted with a full citation of the original source: (Woo \& Cipriano 2017) (Original Publisher: CABI Publishing).

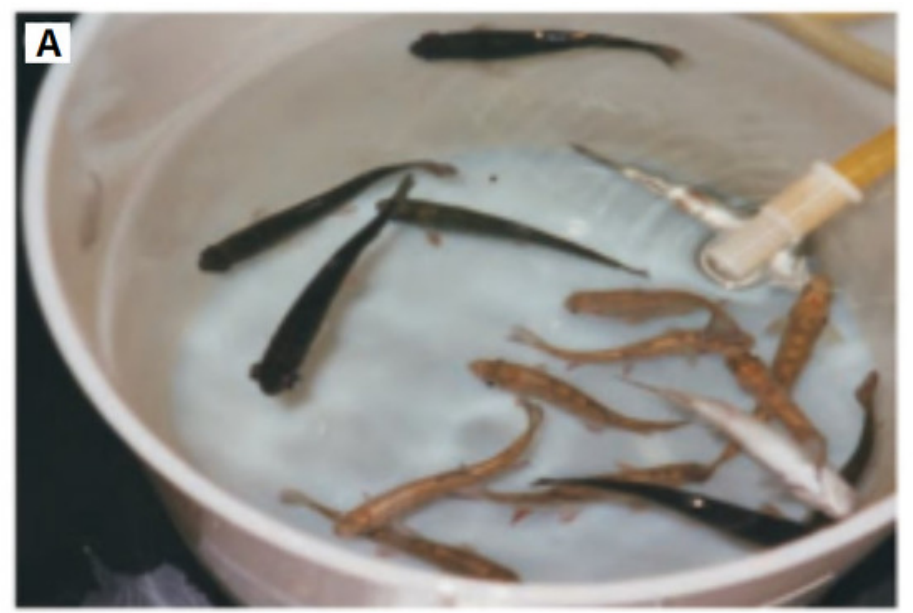

B

\section{C}

